\title{
Synthesis and NMR-characterization of three quinamide-based disaccharide mimetics with unusual cyclohexane twist- conformation $^{\dagger}$
}

\author{
Thuy Trang M. Nguyen, Paul H. Gross, and Andreas H. Franz* \\ Department of Chemistry, University of the Pacific, Stockton, CA 95211 \\ E-mail: afranz@pacific.edu
}

Dedicated to Professor Nikolai S. Zefirov on the occasion of his $70^{\text {th }}$ birthday

(received 20 Feb 05; accepted 15 Apr 05; published on the web 22 Apr 05)

\begin{abstract}
The synthesis of amide-linked disaccharide mimetics has been explored starting with carbohydrate-based amines and a protected quinic acid lactone. Benzyl-2-amino-4,6-Obenzylidene-2-deoxy- $\alpha / \beta$-D-glucopyranose (12) and D-glucamine (14) were successfully coupled to give the corresponding quinamides (13 and 15), while the quinoylation of $O$ acetylated L-fucopyranosyl methylamine (7) failed. The latter was prepared from per-O-acetylL-fucopyranose via the improved multigram scale synthesis of the corresponding per- $O$-acetylL-fucopyranosyl cyanide (3). Compound $\mathbf{3}$ was subsequently hydrogenated to yield a mixture of compound 7 and the per- $O$-acetylated bis-(fucopyranosylmethyl) amine (5). The vicinal coupling constants in the NMR spectra of all quinamide products revealed considerable flexibility of the cyclohexane ring in solution and substantial contributions by twist-chair conformations.
\end{abstract}

Keywords: Aminomethyl- $C$-fucopyranoside, quinic acid, carboxamide, disaccharide mimetics, 2-amino-2-deoxy-D-glucopyranose, D-glucamine, conformational analysis

\section{Introduction}

Recently, oligosaccharides were recognized to have functions influencing the entire spectrum of cell activities ${ }^{1-4}$ For example, carbohydrates have been recognized as a completely new cancer prevention target $^{5-8}$ and as possible vaccines ${ }^{4,9-15}$ Explanations for the striking complexity of naturally occurring carbohydrates have been proposed. ${ }^{16}$

\footnotetext{
${ }^{\dagger}$ In part presented as poster at the $8^{\text {th }}$ Annual Conference of the Society for Glycobiology, San Diego, CA, USA, November 2003.
} 
Availability of metabolically resistant carbohydrate analogs will aid in the study of molecular interactions between carbohydrates and the cell machinery. The synthesis of metabolically stable mimetics of natural carbohydrates as well as oligosaccharides and polyhydroxyl clusters with linkages other than the natural $O$-glycosidic linkage has attracted considerable interest. ${ }^{17,18}$ In this paper, we have investigated the possibility for the synthesis of amide-linked Small Cluster Oligosaccharide Mimetics (SCOM) ${ }^{19-21}$ through nucleophilic opening of a suitably protected lactone from quinic acid by amines to yield disaccharide-like structures. Quinic acid ${ }^{22}$ and especially its derivative shikimic acid ${ }^{23-25}$ are known to be of crucial importance during the biochemical synthesis of essential aromatic amino acids and have attracted wide spread interest. $^{26-27}$

\section{Results and Discussion}

Per- $O$-acetylation of L-fucose on a multigram-scale has not been reported to the best of our knowledge and was carried out by us to yield an anomeric mixture of 1,2,3,4-tetra- $O$-acetyl-Lfucopyranose (2a,b, $98 \%$ overall, $15 \mathrm{~g}$ starting material) with an $\alpha$-/ $\beta$-ratio of $15: 1$ as estimated by ${ }^{1} \mathrm{H}-\mathrm{NMR}$ (Scheme 1). The observed yield indicated no significant side reactions upon scale up and was consistent with previous reports on small scale. ${ }^{28,29}$ Lewis acid-promoted direct displacement of the anomeric acetyl group ${ }^{19,30,31}$ in $\mathbf{2 a , b}$ gave the fucopyranosyl cyanides $\mathbf{3 a}, \mathbf{b}$ $(\alpha / \beta$-ratio $<1: 20$ as estimated by NMR).

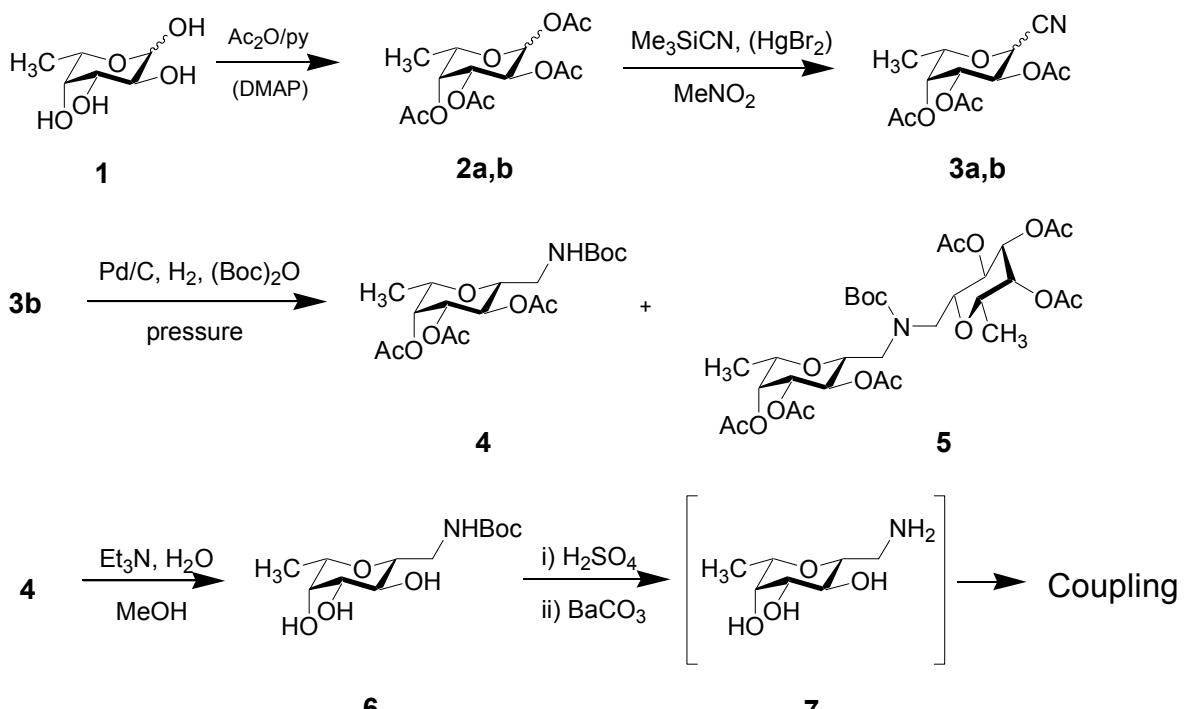

6

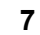

Scheme 1. Conversion of $\mathbf{2} \mathbf{a} / \mathbf{b}$ into the fucopyranosyl cyanides $\mathbf{3 a} / \mathbf{b}$ followed by reduction in the presence of Boc- anhydride. ${ }^{19}$ 
After hydrogenation of compound $\mathbf{3 b},{ }^{19}$ the mixture of $N$-Boc-protected aminomethyl- $C$ monosaccharide 4 and $N$-Boc-protected aminomethyl- $C$-disaccharide $\mathbf{5}$ was separated by flash column chromatography on silica gel. The combined fractions of $\mathbf{4}$ and $\mathbf{5}$ gave an overall yield of $97 \%$. The ${ }^{1} \mathrm{H}-\mathrm{NMR}$ spectra of $\mathbf{4}$ and $\mathbf{5}$ are shown in Figure 1. The proton assignments and coupling constants were consistent with a ${ }^{1} \mathrm{C}_{4}$ solution-conformation ${ }^{32-35}$ in $\mathrm{CDCl}_{3}$ for both 4 and 5. A ${ }^{13} \mathrm{C}$-DEPT experiment (data not shown) confirmed the presence of one $\mathrm{CH}_{2}$-group in 4 and two $\mathrm{CH}_{2}$-groups in $\mathbf{5}$, which supported the monosaccharide structure for the former and the disaccharide structure for the latter.

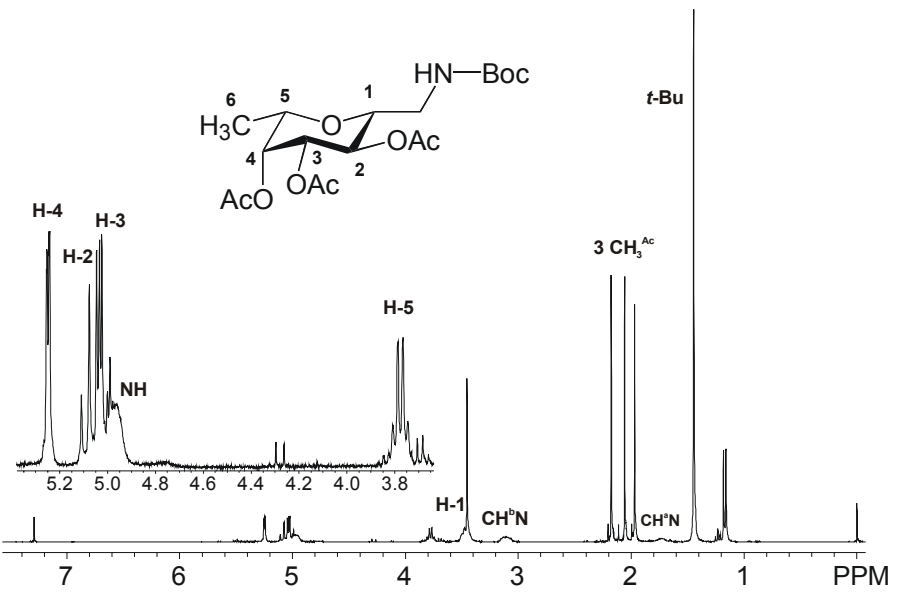

a)

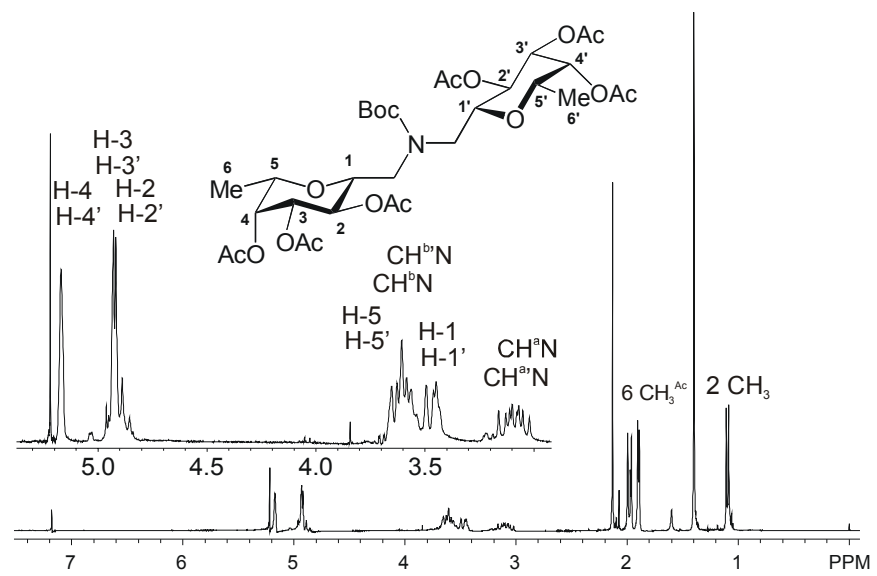

b)

Figure 1. (a) ${ }^{1} \mathrm{H}-\mathrm{NMR}$ spectrum of compound 4 with a 1:3 integration ratio between the fucose6- $\mathrm{CH}_{3}$ group and the $t$-butyl group (solvent $\mathrm{CDCl}_{3}$ ); b) ${ }^{1} \mathrm{H}-\mathrm{NMR}$ spectrum of compound 5 with a $3: 2$ integration ratio between the fucose-6- $\mathrm{CH}_{3}$ group and the $t$-butyl group (solvent $\mathrm{CDCl}_{3}$ ). 
It has been shown in the literature that methoxide-catalyzed global deprotection of structures similar to 4 suffer from unintended migration of the C-2-acetyl group to the nitrogen atom of the aminomethyl group. ${ }^{19}$ However, here we were able to achieve selective de- $O$-acetylation of 4 with a combination of $\mathrm{Et}_{3} \mathrm{~N}$ in aq. $\mathrm{MeOH}$ at rt., which did not affect the Boc group (NMR data not shown) and prevented $O$ - $/ N$-acetyl migration. Compound $\mathbf{6}$ was obtained as a syrup and was immediately subjected to sulfuric acid-catalyzed removal of the Boc group. The subsequent neutralization of sulfuric acid was conveniently achieved by $\mathrm{BaCO}_{3}$, and the resulting precipitate of $\mathrm{BaSO}_{4}$ was filtered off. Compound 7 was found to decompose over time. Therefore, the crude product was coupled immediately with lactone $\mathbf{9}$ whose synthesis from D-(-)-quinic acid $\mathbf{8}$ is shown in Scheme 2. ${ }^{36}$ Compound 9 (91\%) was obtained with identical physical properties to the one described in the literature and with consistent ${ }^{1} \mathrm{H}-\mathrm{NMR}$ data (Table 1).

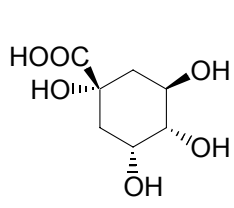

8
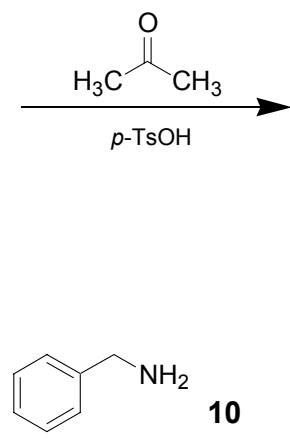

DMA, $70^{\circ} \mathrm{C}$

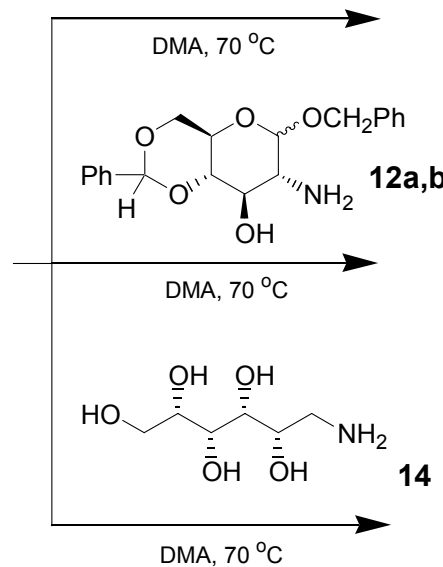<smiles>CC1(C)O[C@H]2C[C@@]3(O)C[C@@H](OC3=O)[C@@H]2O1</smiles>

9

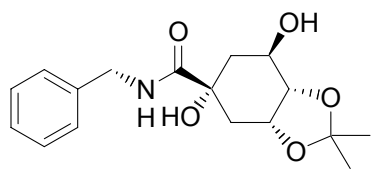

11

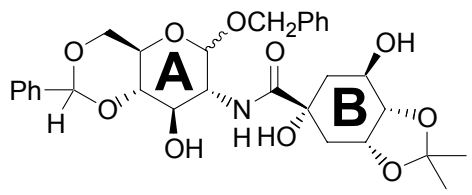

$13 a, b$

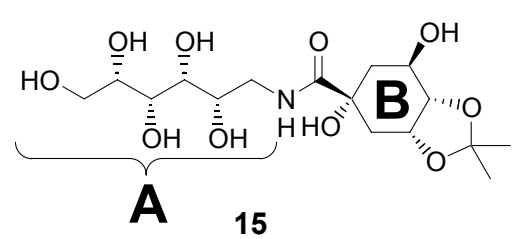

Scheme 2. Synthesis of chiral compound $9^{36}$ from D-(-)-quinic acid and subsequent lactone opening of $\mathbf{9}$ with amines $\mathbf{1 0},{ }^{20,21} \mathbf{1 2 a} / \mathbf{b}$ and $\mathbf{1 4}$. 
Unfortunately, the coupling reaction between compound 7 and 9 did not yield the intended carboxamide product under a variety of reaction conditions. The quinic acid lactone was partly recovered, whereas the remainder was a complex mixture of at least five unidentified compounds. At the present time, we assume that chemical instability of compound 7 prevented the successful synthesis of the amide. Therefore, we investigated compound $\mathbf{9}$ as a coupling partner for amines in two model reactions with aniline and benzylamine. Whereas the reaction with benzylamine $\mathbf{1 0}$ yielded the reported ${ }^{21}$ coupling product $\mathbf{1 1}$ in very good overall yield, the coupling between 9 and aniline did not succeed. Resonance-delocalization of the nitrogen lone pair in aniline and concurrent reduced nucleophilicity may be a possible explanation for this result. The benzyl carboxamide 11 was analyzed by NMR spectroscopy (Figure 2).

The solution data for 11 in $\mathrm{CDCl}_{3}$ indicated a significant $t$ wist-chair conformation. In the ring system of 11, H-3 was significantly shielded compared to 9 (Table 1, vide infra) as a result of lactone opening and small vicinal coupling constants between $\mathrm{H}-3$ and both $\mathrm{H}-2 \mathrm{a}$ and $\mathrm{H}-2 \mathrm{~b}, 5.1$ $\mathrm{Hz}$ and $3.0 \mathrm{~Hz}$, respectively. This was consistent with the $\mathrm{CH}-3$ bond dissecting the $\mathrm{H}-2 \mathrm{a}-\mathrm{C}-\mathrm{H}-$ $2 \mathrm{~b}$ bond angle. Proton 4 was assigned to the signal at $4.17 \mathrm{ppm}$. Besides the two small coupling constants towards $\mathrm{H}-3$ and $\mathrm{H}-5$, the presence of a 4-bond $\mathrm{W}$-coupling of $1.5 \mathrm{~Hz}$ towards $\mathrm{H}-2 \mathrm{~b}$ was observed. This $\mathrm{W}$-coupling was also present in the signal for $\mathrm{H}-2 \mathrm{~b}$ and was confirmed by a weak off-diagonal cross peak in the ${ }^{1} \mathrm{H}-{ }^{1} \mathrm{H}$-COSY spectrum (Figure $2 \mathrm{~b}$ ). The signal for $\mathrm{H}-5$ at 4.58 ppm was split by interaction with $\mathrm{H}-4\left({ }^{3} J_{3,4} 6.9 \mathrm{~Hz}\right)$ and two small gauche couplings of 2.7 $\mathrm{Hz}$ towards H-6a and H-6b. It was concluded, in analogy to H-3, that the CH-5 bond dissected the H-6a-C-H-6b bond angle. Both protons H-3 and H-5 showed NOE cross-peaks to H-2a/H-2b and $\mathrm{H}-6 \mathrm{a} / \mathrm{H}-6 \mathrm{~b}$, respectively (Figure $2 \mathrm{~b}$ ), which cannot be explained by a chair-form and supports a significant contribution by the twist-conformation in $\mathrm{CDCl}_{3}$. This conformation might be favorably supported by a hydrogen bond between the $\mathrm{OH}$ group at $\mathrm{C}-3$ and the carboxamide (Figure 2a). We also detected hydration between the two $\mathrm{OH}$-groups and residual water in the solvent. This resulted in a significant EXSY ${ }^{37,38}$ cross-peak between $\mathrm{OH}-1$ and $\mathrm{OH}-3$ despite the great distance (data not shown). 

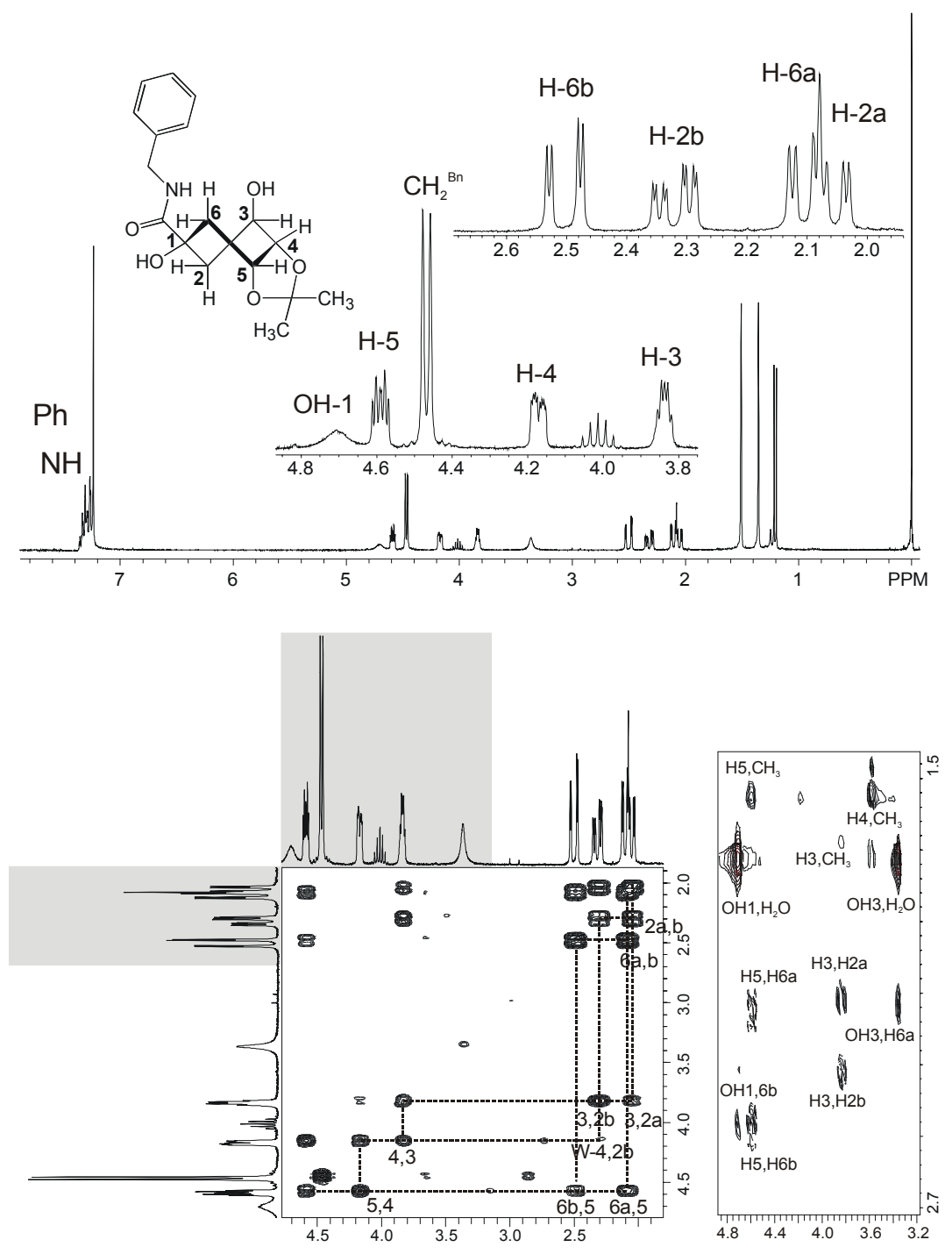

Figure 2. (a) ${ }^{1} \mathrm{H}-\mathrm{NMR}$ spectrum of compound $11\left(\mathrm{CDCl}_{3}\right)$; (b) ${ }^{1} \mathrm{H}-{ }^{1} \mathrm{H}-\mathrm{COSY}$ spectrum (detail, left) and NOESY spectrum (detail, right) of 11.

The lactone 9 was also used in the synthesis of three Small Cluster Oligosaccharide Mimetics (SCOM) with sterically more demanding amines. Benzyl-2-amino-4,6-O-benzylidene-2-deoxy$\alpha$ - and $\beta$-D-glucopyranoside 12a and $\mathbf{1 2} \mathbf{b}^{39,40}$ and D-glucamine 14 were used for coupling with 9. All three amines were successfully coupled, and carboxamides $\mathbf{1 3 a}, \mathbf{1 3 b}$, and $\mathbf{1 5}$, respectively, were obtained in moderate to excellent yields. NMR data for the starting materials $(\mathbf{9}, \mathbf{1 2 a}$ and 12b) and for the products (13a and 13b) are shown in Table 1 for comparison. 
The ${ }^{1} \mathrm{H}-\mathrm{NMR}$ spectrum of 13a recorded in $\mathrm{CDCl}_{3}$ is shown in Figure 3a. A change of solvent to $\mathrm{DMSO}_{-} \mathrm{d}_{6}$ resulted in less useful spectra where heavily overlapped signals of diagnostic protons complicated the overall assignment (data not shown). In $\mathrm{CDCl}_{3}$, the anomeric configurations for the hexapyranosyl rings $\mathrm{A}$ in 13a and 13b were assigned based on the vicinal coupling constants between $\mathrm{H} 1{ }^{\mathrm{A}}$ and $\mathrm{H} 2{ }^{\mathrm{A}}\left({ }^{3} J_{1,2}=3.3 \mathrm{~Hz}\right.$, gauche, $\alpha$-configuration, and ${ }^{3} J_{1,2}=8.1$ $\mathrm{Hz}$, trans-diaxial, $\beta$-configuration, respectively) and did not differ from the starting materials 12a and 12 b (Table 1). In $\mathrm{CDCl}_{3}$ both $\mathrm{OH}$-groups in ring $\mathrm{B}$ were successfully identified based on long-range TOCSY correlations with $\mathrm{H}-6 \mathrm{a} / \mathrm{b}$ and $\mathrm{H}-2 \mathrm{a} / \mathrm{b}$ in ring $\mathrm{B}$ (Figure $3 \mathrm{~b}$, left). The signal of $\mathrm{OH}-3^{\mathrm{B}}$ at 4.39 ppm was split into a doublet by $\mathrm{H}-3^{\mathrm{B}}$, and the remaining $\mathrm{OH}-3$ in ring $\mathrm{A}$ at 3.11

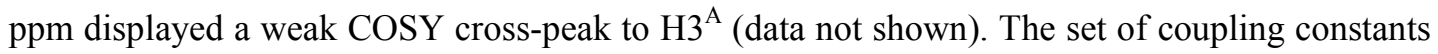
observed in ring $\mathrm{B}$ for 13a was found to be similar to that in compound 11. Both signals for $\mathrm{H}-3^{\mathrm{B}}$ and $\mathrm{H}-5^{\mathrm{B}}$ displayed small vicinal coupling constants towards $\mathrm{H}-2 \mathrm{a} / \mathrm{b}^{\mathrm{B}}$ and $\mathrm{H}-6 \mathrm{a} / \mathrm{b}^{\mathrm{B}}$, respectively. In the molecular model ${ }^{41}$ of the $t$ wist-conformation, the estimated dihedral angles were [H5-C-C$\mathrm{H} 6 \mathrm{a}]+59.9^{\circ}$, [H5-C-C-H6b] $-56.6^{\circ}$, [H3-C-C-H2a] $+52.9^{\circ}$, and [H3-C-C-H2b] $-61.6^{\circ}$. This gauche relationship was in good agreement with the determined small vicinal coupling constants (Table 1). We were able to confirm this assignment by NOESY cross-peaks between $\mathrm{H}-5^{\mathrm{B}} / \mathrm{H}-$ $6 \mathrm{a} / \mathrm{b}^{\mathrm{B}}$ (molecular model: $\mathrm{d}_{5,6 \mathrm{a}} 2.47 \AA$ and $\mathrm{d}_{5,6 \mathrm{~b}} 2.46 \AA$, respectively) and $\mathrm{H}-3^{\mathrm{B}} / \mathrm{H}-2 \mathrm{a} / \mathrm{b}^{\mathrm{B}}$ (molecular model: $\mathrm{d}_{3,2 \mathrm{a}} 2.41 \AA$ and $\mathrm{d}_{3,2 \mathrm{~b}} 2.46 \AA$, respectively) in Figure $3 \mathrm{~b}$ (center). A weak enhancement was also observed between the $\mathrm{OH}$-group on $\mathrm{C}-3$ and $\mathrm{H}_{6} \mathrm{a}^{\mathrm{B}}$. The conformation of ring $\mathrm{A}$ is defined by the trans-fused 4,6-O-benzylidene protection group, and all observed coupling constants and NOE-enhancements were fully consistent with the ${ }^{4} \mathrm{C}_{1}$-conformation (Table 1). Inter-ring cross-peaks were observed only among the three $\mathrm{OH}$-groups (Figure $3 \mathrm{~b}$, right). We concluded that residual water in $\mathrm{CDCl}_{3}$ connected the $\mathrm{OH}$-groups in both rings through hydrogen-bonded $\mathrm{H}_{2} \mathrm{O}$-molecules that can give rise to EXSY cross-peaks through chemical exchange. ${ }^{37,38}$ The exact geometry of this hydration feature was not further investigated by us and will be subject of future studies. NOESY cross-peaks from the amide proton with $\mathrm{H}-2^{\mathrm{A}}$ $\left(\mathrm{d}_{\mathrm{NH}, 2} 2.94 \AA\right)$ and $\mathrm{H}-3^{\mathrm{A}}\left(\mathrm{d}_{\mathrm{NH}, 3} 2.44 \AA\right)$ were also observed. 

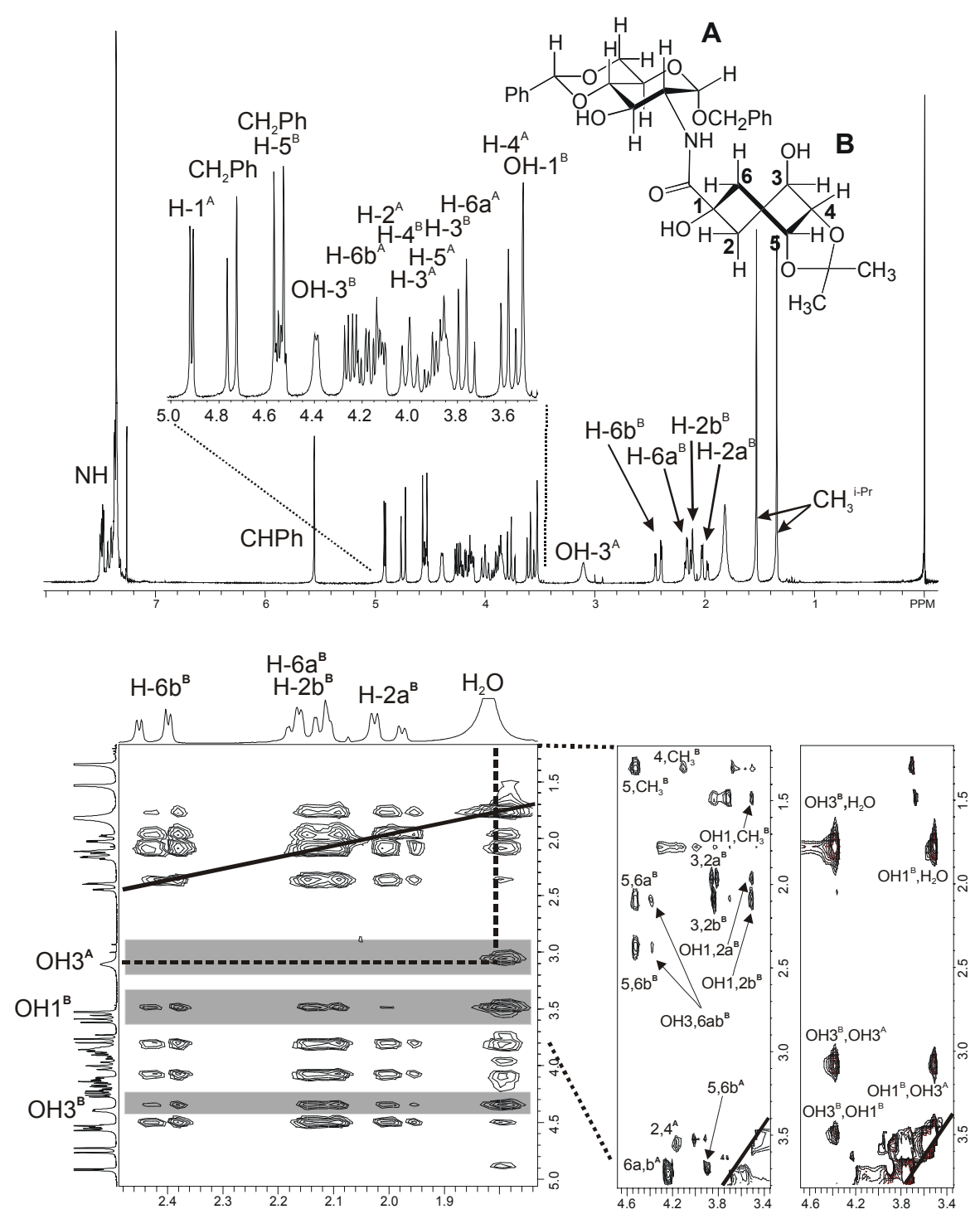

Figure 3. (a) ${ }^{1} \mathrm{H}-\mathrm{NMR}$ spectrum of compound 13a (solvent $\mathrm{CDCl}_{3}$ ); (b) ${ }^{1} \mathrm{H}-{ }^{1} \mathrm{H}$-TOCSY spectrum detail (left), NOESY spectrum detail (positive contours, center), and NOESY spectrum detail (negative contours, right) of 13a. The diagonal is indicated. 
Table 1. ${ }^{1} \mathrm{H}-\mathrm{NMR}$ shift values for $\mathbf{9}, \mathbf{1 1}, \mathbf{1 2 a} / \mathbf{b}$, and $\mathbf{1 3 a} / \mathbf{b}$. $\boldsymbol{J}$-values in $\mathrm{Hz}$

\begin{tabular}{|c|c|c|c|c|c|c|}
\hline Proton & $\begin{array}{c}\mathbf{9} \\
\mathrm{CDCL}_{3}\end{array}$ & $\begin{array}{c}11 \\
\mathrm{CDCl}_{3}\end{array}$ & $\begin{array}{c}\mathbf{1 2 a} \\
\mathrm{CDCl}_{3}\end{array}$ & $\begin{array}{c}\mathbf{1 3 a} \\
\mathrm{CDCl}_{3}\end{array}$ & $\begin{array}{c}\mathbf{1 2 b} \\
\mathrm{CDCl}_{3}\end{array}$ & $\begin{array}{c}\mathbf{1 3 b} \\
\mathrm{CDCl}_{3}\end{array}$ \\
\hline $\mathbf{1}^{\mathrm{A}}$ & - & - & $\begin{array}{l}4.90(\mathrm{~d}) \\
{ }^{3} J_{1,2}=3.6\end{array}$ & $\begin{array}{l}4.91(\mathrm{~d}) \\
{ }^{3} J_{1,2}=3.3\end{array}$ & $\begin{array}{l}4.37(\mathrm{~d}) \\
{ }^{3} J_{1,2}=7.8\end{array}$ & $\begin{array}{l}4.72(\mathrm{~d}) \\
{ }^{3} J_{1,2}=8.1\end{array}$ \\
\hline $2^{A}$ & - & - & $\begin{array}{l}2.79(\mathrm{dd}) \\
{ }^{3} J_{2,1}=3.9 \\
{ }^{3} J_{2,3}=9.6\end{array}$ & $\begin{array}{c}4.19(\mathrm{dt}) \\
{ }^{3} J_{2,1}=3.9 \\
{ }^{3} J_{2,3}=9.9 \\
{ }^{3} J_{2, \mathrm{NH}}=9.9\end{array}$ & $\begin{array}{l}2.85(\mathrm{t}), \\
{ }^{3} J_{2,1}=8.4 \\
{ }^{3} J_{2,3}=8.4\end{array}$ & $\begin{array}{c}3.68 \text { (ddd) } \\
{ }^{3} J_{2,1}=8.1 \\
{ }^{3} J_{2,3}=9.6 \\
{ }^{3} J_{2, \mathrm{NH}}=7.2\end{array}$ \\
\hline $3^{A}$ & - & - & $\begin{array}{c}3.74(\mathrm{t}) \\
{ }^{3} J_{3,2}=10.2 \\
{ }^{3} J_{3,4}=10.2\end{array}$ & $\begin{array}{c}4.00(\mathrm{t}) \\
{ }_{3}^{3} J_{3,2}=9.3 \\
{ }^{3} J_{3,4}=9.3\end{array}$ & $\begin{array}{c}3.58(\mathrm{dd}),{ }^{3} J_{3,2}=8.4 \\
{ }^{3} J_{3,4}=10.8\end{array}$ & $\begin{array}{l}4.05(\mathrm{dd}) \\
{ }_{3}^{3} J_{3,2}=9.9 \\
{ }_{3,4}=9.0\end{array}$ \\
\hline $4^{\mathrm{A}}$ & - & - & $\begin{array}{l}3.48(\mathrm{t}) \\
{ }^{3} J_{4,3}=9.3 \\
{ }^{3} J_{4,5}=9.3\end{array}$ & $\begin{array}{l}3.59(\mathrm{t}) \\
{ }^{3} J_{4,3}=9.0 \\
{ }^{3} J_{4,5}=9.0\end{array}$ & $\begin{array}{l}3.81(\mathrm{t}) \\
{ }^{3} J_{4,3}=9.9 \\
{ }^{3} J_{4,5}=9.9\end{array}$ & $\begin{array}{c}3.59(\mathrm{t}) \\
{ }^{3} J_{4,3}=9.0 \\
{ }^{3} J_{4,5}=9.0\end{array}$ \\
\hline $5^{\mathrm{A}}$ & - & - & $\begin{array}{c}3.87(\mathrm{dt}),{ }^{3} J_{5,4}=9.9 \\
{ }_{5,6 \mathrm{a}}=4.5 \\
{ }^{3} J_{5,6 \mathrm{~b}}=9.9\end{array}$ & $\begin{array}{l}3.90(\mathrm{dt}) \\
{ }^{3} J_{5,4}=9.9 \\
{ }^{3} J_{5,6 \mathrm{a}}=4.5 \\
{ }^{3} J_{5,6 \mathrm{~b}}=9.9\end{array}$ & $\begin{array}{c}3.44(\mathrm{ddd}),{ }^{3} J_{5,4}=8.7 \\
{ }^{3} J_{5,6 \mathrm{a}}=4.2 \\
{ }^{3} J_{5,6 \mathrm{~b}}=13.8\end{array}$ & $\begin{array}{l}3.47(\mathrm{dt}) \\
{ }^{3} J_{5,4}=9.6 \\
{ }^{3} J_{5,6 \mathrm{a}}=9.6 \\
{ }^{3} J_{5,6 \mathrm{~b}}=4.8\end{array}$ \\
\hline $6 a^{A}$ & - & - & $\begin{array}{c}4.23(\mathrm{dd}) \\
3_{6 \mathrm{a}, 5}=4.5 \\
{ }^{3} J_{6 \mathrm{a}, 6 \mathrm{~b}}=9.9\end{array}$ & $\begin{array}{c}3.76(\mathrm{t}) \\
3_{6 \mathrm{a}, 5}=9.9 \\
{ }^{3} J_{6 \mathrm{a}, 6 \mathrm{~b}}=9.9\end{array}$ & $\begin{array}{c}4.35(\mathrm{dd}),{ }^{3} J_{6 \mathrm{a}, 5}=4.8 \\
{ }^{3} J_{6 \mathrm{a}, 6 \mathrm{~b}}=11.1\end{array}$ & $\begin{array}{c}3.82(\mathrm{t} \sim \mathrm{dd}) \\
3_{6 \mathrm{a}, 5}=9.9 \\
{ }^{3} J_{6 \mathrm{a}, 6 \mathrm{~b}}=10.5\end{array}$ \\
\hline $6 b^{A}$ & - & - & $\begin{array}{c}3.75(\mathrm{t}),{ }^{3} J_{6 \mathrm{~b}, 5}=9.3 \\
{ }^{3} J_{6 \mathrm{~b}, 6 \mathrm{a}}=9.3\end{array}$ & $\begin{array}{l}4.25(\mathrm{dd}) \\
{ }^{3} J_{6 \mathrm{~b}, 5}=4.5 \\
{ }^{3} J_{6 \mathrm{~b}, 6 \mathrm{a}}=9.9\end{array}$ & $\begin{array}{c}3.56(\mathrm{dd}),{ }^{3} J_{6 \mathrm{~b}, 5}=14.1 \\
{ }^{3} J_{6 \mathrm{~b}, 6 \mathrm{a}}=10.8\end{array}$ & $\begin{array}{c}4.37(\mathrm{dd}) \\
{ }^{3} J_{6 \mathrm{~b}, 5}=4.5 \\
{ }^{3} J_{6 \mathrm{~b}, 6 \mathrm{a}}=10.5\end{array}$ \\
\hline CHPh & - & $4.45 \overline{(\mathrm{dd} \sim \mathrm{d})}$ & $\begin{array}{c}5.53 \\
4.51(\mathrm{~d})\end{array}$ & $\begin{array}{l}5.56(\mathrm{~s}) \\
4.55(\mathrm{~d})\end{array}$ & $\begin{array}{l}5.55(\mathrm{~s}) \\
4.60(\mathrm{~d})\end{array}$ & $\begin{array}{l}5.55(\mathrm{~s}) \\
4.61(\mathrm{~d})\end{array}$ \\
\hline $\mathrm{CH}_{2} \mathrm{Ph}$ & - & $\begin{array}{l}4.48(\mathrm{dd} \sim \mathrm{d}) \\
\text { AB-mixing }\end{array}$ & $\begin{array}{l}4.74(\mathrm{~d}) \\
{ }^{2} J=11.7\end{array}$ & $\begin{array}{l}4.74(\mathrm{~d}) \\
{ }^{2} J=12.0\end{array}$ & $\begin{array}{l}4.90(\mathrm{~d}) \\
{ }^{2} J=11.4\end{array}$ & $\begin{array}{l}4.89(\mathrm{~d}) \\
{ }^{2} J=11.7\end{array}$ \\
\hline OH & - & - & 1.9 (br) & $3.11(\mathrm{~s}, \mathrm{br})$ & $2.3(\mathrm{br})$ & $3.00(\mathrm{~s})$ \\
\hline $\mathbf{N H}_{2}$ & - & - & 1.9 (br) & - & 2.3 (br) & - \\
\hline $\mathbf{N H}^{\text {amide }}$ & $\begin{array}{c}- \\
2.65(\mathrm{~d})\end{array}$ & $\begin{array}{c}7.34(\mathrm{t}) \\
{ }^{3} J_{\mathrm{NH}, \mathrm{CH} 2}=2.1 \\
2.05(\mathrm{dd})\end{array}$ & - & $\begin{array}{c}\sim 7.4 \\
(\text { subm.) } \\
2.00(\mathrm{dd})\end{array}$ & - & $\begin{array}{c}7.29(\mathrm{~d}) \\
{ }^{3} J_{\mathrm{NH}, 2}=7.8 \\
2.01(\mathrm{dd})\end{array}$ \\
\hline $\mathrm{H} 2 \mathrm{a}^{\mathrm{B}}$ & $\begin{array}{c}{ }^{3} J_{2 \mathrm{~b}, 3}<1 \\
{ }^{2} J_{2 \mathrm{~b}, 2 \mathrm{a}}=11.7\end{array}$ & $\begin{array}{c}{ }^{3} J_{2 \mathrm{a}, 3}=2.7 \\
{ }^{2} J_{2 \mathrm{a}, 2 \mathrm{~b}}=11.7\end{array}$ & - & $\begin{aligned}{ }^{3} J_{2 \mathrm{a}, 3} & =3.3 \\
{ }^{2} J_{2 \mathrm{a}, 2 \mathrm{~b}} & =15.0\end{aligned}$ & - & $\begin{aligned}{ }^{3} J_{2 \mathrm{a}, 3} & =3.0 \\
{ }^{2} J_{2 \mathrm{a}, 2 \mathrm{~b}} & =15.0\end{aligned}$ \\
\hline $\mathbf{H} 2 \mathbf{b}^{\mathrm{B}}$ & $\begin{array}{c}2.30 \text { (ddt) } \\
{ }^{4} J_{2 \mathrm{a}, 4}=2.1 \\
{ }^{4} J_{2 \mathrm{a}, \mathrm{aa}}=2.1 \\
{ }^{3} J_{2 \mathrm{a}, 3}=6.0 \\
{ }^{2} J_{2 \mathrm{a}, 2 \mathrm{~b}}=12.0 \\
\end{array}$ & $\begin{array}{c}2.32(\mathrm{ddd}) \\
{ }^{4} J_{2 \mathrm{~b}, 4}=1.5 \\
{ }^{3} J_{2 \mathrm{~b}, 3}=5.1 \\
{ }^{2} J_{2 \mathrm{~b}, 2 \mathrm{a}}=14.7\end{array}$ & - & $\begin{array}{c}2.15(\mathrm{ddd}) \\
{ }^{4} J_{2 \mathrm{~b}, 4}=0.9 \\
{ }^{3} J_{2 \mathrm{~b}, 3}=5.7 \\
{ }^{2} J_{2 \mathrm{~b}, 2 \mathrm{a}}=14.7\end{array}$ & - & $\begin{array}{c}2.20(\mathrm{ddd}) \\
{ }^{4} J_{2 \mathrm{~b}, 4}=0.9 \\
{ }^{3} J_{2 \mathrm{~b}, 3}=5.7 \\
{ }^{2} J_{2 \mathrm{~b}, 2 \mathrm{a}}=14.7\end{array}$ \\
\hline $\mathrm{H3}^{\mathrm{B}}$ & $\begin{array}{c}4.71(\mathrm{dd}) \\
{ }^{3} J_{3,2 \mathrm{a}}=6.0 \\
{ }^{3} J_{3,2 \mathrm{~b}}<1 \\
{ }^{3} J_{3,4}=2.4\end{array}$ & $\begin{array}{l}3.84(\mathrm{dt}) \\
{ }^{3} J_{3,2 \mathrm{a}}=3.0 \\
{ }^{3} J_{3,2 \mathrm{~b}}=5.1 \\
{ }^{3} J_{3,4}=3.0\end{array}$ & - & $\begin{array}{c}\sim 3.8 \\
(\text { subm. })\end{array}$ & - & $\begin{array}{c}\sim 3.8 \\
(\text { subm.) }\end{array}$ \\
\hline$H 4^{\mathrm{B}}$ & $\begin{array}{c}4.29(\mathrm{ddd}) \\
{ }^{4} J_{4,6 \mathrm{a}}=3.6 \\
{ }^{3} J_{4,3}=2.4 \\
{ }^{3} J_{4,5}=6.6 \\
4.48 \text { (ddd } \sim \mathrm{dt})\end{array}$ & $\begin{array}{l}4.17 \text { (ddd) } \\
{ }^{4} J_{4,2 b}=1.5 \\
{ }^{3} J_{4,3}=3.0 \\
{ }^{3} J_{4,5}=6.6 \\
4.59(\mathrm{dt})\end{array}$ & - & $\begin{array}{c}4.12(\mathrm{ddd} \sim \mathrm{dd}) \\
{ }^{4} J_{4,2 \mathrm{~b}}<1 \\
{ }^{3} J_{4,3}=3.3 \\
{ }^{3} J_{4,5}=6.6 \\
4.54(\mathrm{dt})\end{array}$ & - & $\begin{array}{c}4.12(\mathrm{ddd} \sim \mathrm{dd}) \\
{ }_{4} J_{4,2 \mathrm{~b}}<1 \\
{ }^{3} J_{4,3}=3.3 \\
{ }^{3} J_{4,5}=6.3 \\
4.53(\mathrm{dt})\end{array}$ \\
\hline $\mathbf{H} 5^{\mathrm{B}}$ & $\begin{array}{c}4.48(\mathrm{ddd} \sim \mathrm{dt}) \\
{ }^{3} J_{5,4}=6.6 \\
{ }^{3} J_{5,6 \mathrm{a}}=6.6 \\
{ }^{3} J_{5,6 \mathrm{~b}}=2,4 \\
2.17(\mathrm{dd})\end{array}$ & $\begin{array}{l}4.59(\mathrm{dt}) \\
{ }^{3} J_{5,4}=6.9 \\
{ }^{3} J_{5,6 \mathrm{a}}=2.7 \\
{ }^{3} J_{5,6 \mathrm{~b}}=2.7 \\
2.11(\mathrm{dd})\end{array}$ & - & $\begin{array}{l}4.54(\mathrm{dt}) \\
{ }^{3} J_{5,4}=6.3 \\
{ }^{3} J_{5,6 \mathrm{a}}=2.7 \\
{ }^{3} J_{5,6 \mathrm{~b}}=2.7 \\
2.14(\mathrm{dd})\end{array}$ & - & $\begin{array}{l}4.53(\mathrm{dt}) \\
{ }^{3} J_{5,4}=6.9 \\
{ }^{3} J_{5,6 \mathrm{a}}=3.0 \\
{ }^{3} J_{5,6 \mathrm{~b}}=3.0 \\
2.02(\mathrm{dd})\end{array}$ \\
\hline${ }^{H 6} \mathbf{a}^{\mathrm{B}}$ & $\begin{aligned}{ }^{3} J_{6 \mathrm{~b}, 5} & =2.7 \\
{ }^{2} J_{6 \mathrm{~b}, 6 \mathrm{a}} & =14.7\end{aligned}$ & $\begin{aligned}{ }^{3} J_{6 \mathrm{a}, 5} & =3.3 \\
{ }^{2} J_{6 \mathrm{a}, \mathrm{bb}} & =12.0\end{aligned}$ & - & $\begin{array}{c}J_{6 \mathrm{a}, 5}=2.1 \\
{ }^{2} J_{6 \mathrm{a}, \mathrm{b}}=15.3\end{array}$ & - & $\begin{array}{c}3_{6 \mathrm{a}, 5}=3.6 \\
{ }^{2} J_{6 \mathrm{a}, \mathrm{b}}=15.3\end{array}$ \\
\hline $46 b^{B}$ & $\begin{array}{c}2.35 \text { (ddd) } \\
{ }^{4} J_{6 \mathrm{a}, 4}=2.7 \\
{ }^{3} J_{6 \mathrm{a}, 5}=7.8 \\
{ }^{2} J_{6 \mathrm{a}, 6 \mathrm{~b}}=15.0\end{array}$ & $\begin{array}{c}2.50(\mathrm{dd}) \\
{ }^{3} J_{6 \mathrm{~b}, 5}=2.1 \\
{ }^{2} J_{6 \mathrm{~b}, \mathrm{aa}}=15.3\end{array}$ & - & $\begin{aligned} & 2.42(\mathrm{dd}) \\
&{ }^{3} J_{6 \mathrm{~b}, 5}=2.4 \\
&{ }^{2} J_{6 \mathrm{~b}, 6 \mathrm{a}}=15.6\end{aligned}$ & - & $\begin{aligned} & 2.37(\mathrm{dd}) \\
&{ }^{3} J_{6 \mathrm{~b}, 5}=2.7 \\
&{ }^{2} J_{6 \mathrm{~b}, 6 \mathrm{a}}=15.9\end{aligned}$ \\
\hline $\mathrm{OH} 1^{\mathrm{B}}$ & $2.64(\mathrm{~s})$ & 4.71 (br) & - & $3.53(\mathrm{~s})$ & - & Not ident. \\
\hline $\mathrm{OH}^{\mathrm{B}}$ & - & 3.37 (br) & - & $\begin{array}{c}4.39(\mathrm{~d}) \\
{ }^{3} J_{\mathrm{OH}, 3}=3.6\end{array}$ & - & Not ident. \\
\hline $\mathrm{CH}_{3}{ }^{\mathrm{i}-\mathrm{Pr}}$ & $\begin{array}{l}1.32(\mathrm{~s}) \\
1.52(\mathrm{~s})\end{array}$ & $\begin{array}{l}1.36(\mathrm{~s}) \\
1.51(\mathrm{~s})\end{array}$ & - & $\begin{array}{l}1.35(\mathrm{~s}) \\
1.53(\mathrm{~s})\end{array}$ & - & $\begin{array}{l}1.35(\mathrm{~s}) \\
1.52(\mathrm{~s})\end{array}$ \\
\hline
\end{tabular}


The ${ }^{1} \mathrm{H}-\mathrm{NMR}$ spectrum for compound $\mathbf{1 3 b}$ is shown in Figure 4a. We observed only a small difference in chemical shift for the anomeric proton $\left(4.71 \mathrm{ppm},{ }^{3} \boldsymbol{J}_{1,2} 8.1 \mathrm{~Hz}\right.$ ) compared to compound 13a with $\alpha$-configuration in the sugar moiety $\left(4.85 \mathrm{ppm},{ }^{3} \boldsymbol{J}_{1,2} 3.0 \mathrm{~Hz}\right)$. However, the vicinal coupling constants ${ }^{3} \boldsymbol{J}_{1,2}$ was indicative of the anomeric configuration. The NMR data obtained for compound 13b suggested similar overall ring conformations in A and B compared to $13 a$ (Figure $4 a$, Table 1).
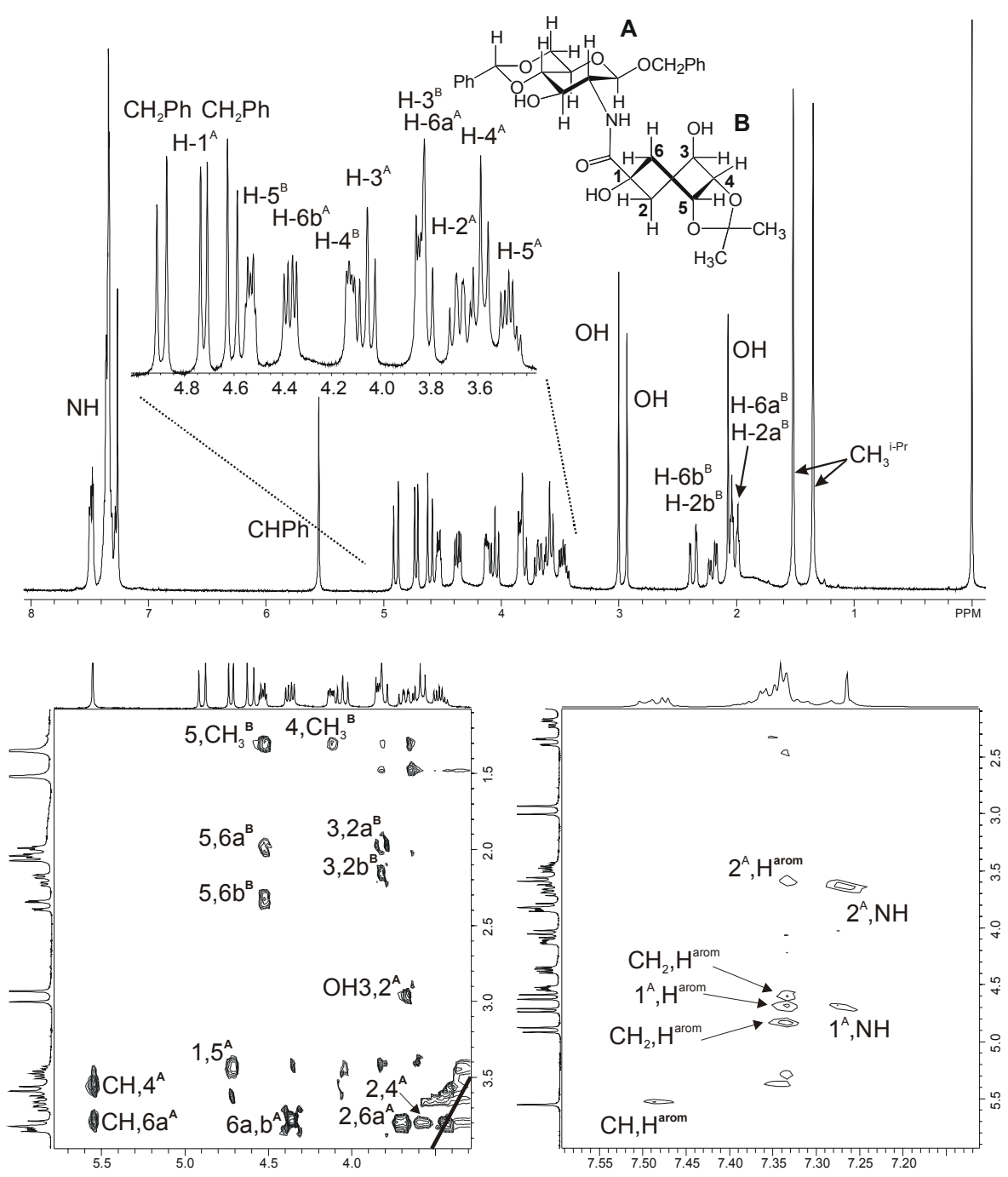

Figure 4. (a) ${ }^{1} \mathrm{H}-\mathrm{NMR}$ spectrum of compound 13b (solvent $\mathrm{CDCl}_{3}$ ); (b) NOESY spectrum details of $\mathbf{1 3 b}$. 
Interestingly, all three $\mathrm{OH}$-signals were sharp singlets at $2.07,2.93$, and $3.00 \mathrm{ppm}$ with only minor line broadening. Neither ${ }^{1} \mathrm{H}-{ }^{1} \mathrm{H}-\mathrm{COSY}$ nor long-range TOCSY data allowed us to assign the signals unequivocally except for $\mathrm{OH}-3^{\mathrm{A}}(3.00 \mathrm{ppm})$ by an NOE cross-peak towards $\mathrm{H}-2^{\mathrm{A}}$ (Figure 4b). However, the NOESY spectrum did not show any EXSY cross peaks among the $\mathrm{OH}$-groups despite the presence of $\mathrm{H}_{2} \mathrm{O}$ in $\mathrm{CDCl}_{3}$. This implied that $\mathbf{1 3 \mathbf { b }}$ was less hydrated and that the $\mathrm{OH}$-groups were possibly stabilized more effectively by intra-molecular hydrogen bonds than 13a. This was supported by observed NOE enhancements between the amide proton and $\mathrm{H}-$ $1^{\mathrm{A}}$ and $\mathrm{H}-2^{\mathrm{A}}$ and a weak NOE signal towards $\mathrm{H}-3^{\mathrm{A}}$ (Figure $4 \mathrm{~b}$ ). This geometry would allow not only the formation of a hydrogen bond between the amide carbonyl oxygen and $\mathrm{OH}-3^{\mathrm{A}}$ as well as $\mathrm{OH}-1^{\mathrm{B}}(1.69 \AA$ and $2.09 \AA$ estimated, respectively) but also between the amide proton and the oxygen of $\mathrm{OH}-3^{\mathrm{B}}(1.71 \AA$ estimated).

The coupling reaction between 9 and recrystallized D-glucamine yielded the expected carboxamide 15 in low yield. Upon recrystalliztion and charcoal treatment of the crude Dglucamine, the yield of the coupling reaction improved to $62 \%$. The isolated product had gelatinous consistency and dried into an amorphous powder with uncharacteristic melting point. The NMR spectrum in DMSO- $\mathrm{d}_{6}$ was found to be consistent with the proposed structure (data not shown). However, extensive overlap especially of signals from the glucamine chain "A" made the full assignment of the structure difficult. In ring $\mathrm{B}$, the proton $\mathrm{H}-3^{\mathrm{B}}$ was identified at $3.65 \mathrm{ppm}$ and $\mathrm{H}-4^{\mathrm{B}}, \mathrm{H}-5^{\mathrm{B}}$, and $\mathrm{H}-6 \mathrm{~b}^{\mathrm{B}}$ at $3.98 \mathrm{ppm}, 4.51 \mathrm{ppm}$, and $2.28 \mathrm{ppm}$, respectively. The three latter showed coupling constants that were similar to the values observed for $\mathbf{1 3 a}$, and $\mathbf{1 3 b}$ in DMSO-d 6 (data not shown).

Temperature-annealed molecular dynamics at $400 \mathrm{~K}$ in vacuum without distance restraints yielded chair-conformations for ring B in compound 11 and in both stereoisomers 13a and 13b. The energy difference between the two possible lowest-energy chair conformations for ring $\mathrm{B}$ was small for all compounds (11: $0.4 \mathrm{kcal} / \mathrm{mol}, \mathbf{1 3 a}$ and $13 \mathrm{~b}: 0.6 \mathrm{kcal} / \mathrm{mol}$ and $1.5 \mathrm{kcal} / \mathrm{mol}$, respectively). In all cases, the amide group and the $\mathrm{OH}-3$ group assumed the axial orientation for favorable hydrogen-bonding in the lowest-energy structure. The observation of a hydrogen bond in the models is a reasonable argument in non-polar solvents such as $\mathrm{CDCl}_{3}$. In this particular conformation, $\mathrm{H}-5^{\mathrm{B}}$ has a gauche relationship towards $\mathrm{H}-6 \mathrm{~b}^{\mathrm{B}}$ and a trans-diaxial position towards $\mathrm{H}-6 \mathrm{a}^{\mathrm{B}}$. Proton $\mathrm{H}-3^{\mathrm{B}}$ would be gauche to both $\mathrm{H}-2 \mathrm{a}^{\mathrm{B}}$ and $\mathrm{H}-2 \mathrm{~b}^{\mathrm{B}}$ with expected coupling constants between 3-5 Hz. However, the experimental coupling constants for 11, 13a, 13b (Table 1), and 15 (acetone- $\mathrm{d}_{6}$, entry not shown: ${ }^{3} J_{5,6 \mathrm{a}}=3.9 \mathrm{~Hz},{ }^{3} J_{5,6 \mathrm{~b}}=3.9 \mathrm{~Hz}$ ) indicated that $\mathrm{H}-5^{\mathrm{B}}$ is gauche to both protons in position 6 and that the dihedral angles between $\mathrm{H}-3^{\mathrm{B}}$ and $\mathrm{H}-2 \mathrm{a}, \mathrm{b}^{\mathrm{B}}$ are rather $\sim 80^{\circ}$ and $\sim 40^{\circ}$, respectively (Table 1,15 entry not shown: signals submerged). Compound 15 could not be analyzed in $\mathrm{CDCl}_{3}$ because of low solubility and, unlike 11, 13a, and 13b, the exact conformation of $\mathbf{1 5}$ could not be established unequivocally. When we switched to DMSO$\mathrm{d}_{6}$, we observed a moderate change in coupling constants for $\mathrm{H}^{\mathrm{B}}$ and $\mathrm{H} 6 \mathrm{a}, \mathrm{b}^{\mathrm{B}}$ in 13a and 13b. Even though the vicinal coupling constants between $\mathrm{H}-5^{\mathrm{B}}$ and $\mathrm{H}-6 \mathrm{a}^{\mathrm{B}} / \mathrm{H}-6 \mathrm{~b}^{\mathrm{B}}$ increased from $2.7-$ $3.0 \mathrm{~Hz}$ in $\mathrm{CDCl}_{3}$ to $5.1-5.4 \mathrm{~Hz}$ in DMSO, they remained identical in value consistent with a bisecting geometry between $\mathrm{C}-\mathrm{H} 5^{\mathrm{B}}$ and the $\mathrm{H} 6 \mathrm{a}^{\mathrm{B}}-\mathrm{C}-\mathrm{H} 6 \mathrm{~b}^{\mathrm{B}}$ angle as described above. 
Unfortunately, the signals of $\mathrm{H}-2 \mathrm{a}^{\mathrm{B}} / \mathrm{H}-2 \mathrm{~b}^{\mathrm{B}}$ (AB-mixing), $\mathrm{H}-3^{\mathrm{B}} / \mathrm{H}-4^{\mathrm{B}}$ (submerged) could not be used to establish the overall conformation of ring B in DMSO reliably. Many of the experimental ${ }^{3} J_{\mathrm{HH}}$ values did not match the calculated values ${ }^{42,43}$ (data not shown) neither for any individual conformation nor for an equilibrium of two chair conformers. This also suggests that several solution conformers, including twist-forms, are in rapid equilibrium, and that vicinal coupling constants and NOE signals have to be interpreted with caution.
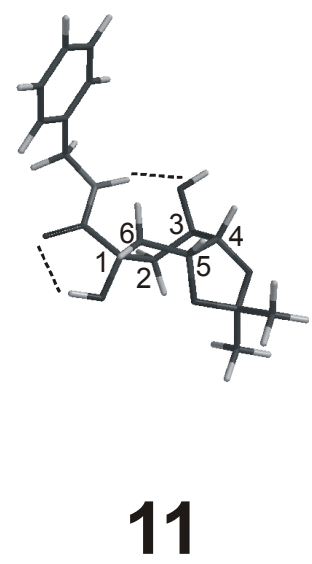

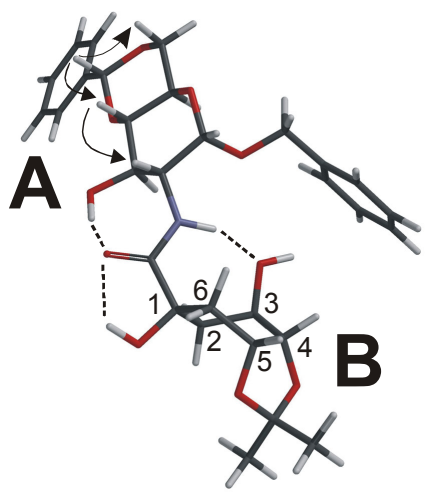

$13 a$

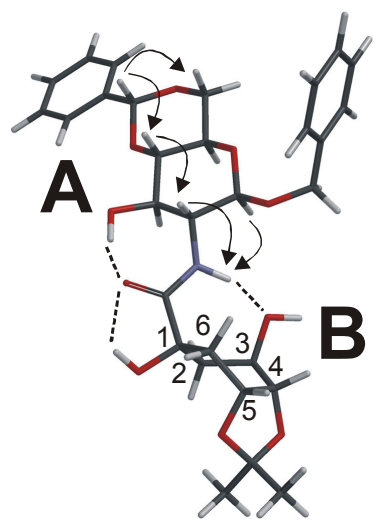

$13 b$

Figure 5. Molecular models ${ }^{41}$ of compounds 11, 13a, and 13b in vacuum. The twistconformations were minimized on the semi-empirical level (AM1-method). H-bonds are shown as dashed lines. Selected experimental NOEs are indicated by arrows.

We modeled compounds 11, 13a, and 13b in their twist-conformations as shown in Figure 5 to approximate the observed solution data and to match the structure with the observed NOE signals. The lowest-energy twist-chair conformation of $\mathbf{1 1}$ was less stable than the two chair conformations by $0.8 \mathrm{kcal} / \mathrm{mol}$ and $0.4 \mathrm{kcal} / \mathrm{mol}$, respectively. In the molecular model of 11 , the geometry of the amide linkage was defined by two hydrogen bonds, one between the amide carbonyl oxygen and the $\mathrm{OH}$-group at $\mathrm{C}$-1; the other one between the amide $\mathrm{NH}$-group and the $\mathrm{OH}$-group at $\mathrm{C}-3$. The latter can be assumed to possibly contribute to the stabilization of the twist-chair observed by NMR. Similar conformational features were observed in the molecular model of 13a and 13b. In both structures, the amide linkage displayed three stabilizing hydrogen bonds. One between $\mathrm{C}=\mathrm{O} / \mathrm{OH}-1^{\mathrm{B}}$ and one between $\mathrm{NH} / \mathrm{OH}-3^{\mathrm{B}}$ (see molecular model 11). An additional hydrogen bond resulted from interaction of the amide carbonyl oxygen and the $\mathrm{OH}$ group at $\mathrm{C}-3^{\mathrm{A}}$ in the glucopyranosyl ring. The location of the amide NH-group between $\mathrm{H}-\mathrm{1}^{\mathrm{A}}$ and $\mathrm{H}-2^{\mathrm{A}}$ was supported by an observed Nuclear Overhauser enhancement in compound 13b (Figure 4), whereas the same NOE-signal was absent in 13a. The lowest-energy twist-chair conformation of $\mathbf{1 3 a}$ was less stable by 3.7 and $4.3 \mathrm{kcal} / \mathrm{mol}$, respectively, and for $\mathbf{1 3 \mathbf { b }}$ values of 
$2.4 \mathrm{kcal} / \mathrm{mol}$ and $0.9 \mathrm{kcal} / \mathrm{mol}$, respectively, were calculated (Figure 5). In view of the significant change in free energy for the twist-conformation in 13a, we assume that the observed hydration feature in 13a is crucial in providing conformational stabilization to account for the observed NMR data.

A full conformational analysis of this system is underway to determine the contribution of all solution conformations to the experimentally observed NMR coupling constants. At the present time we assume that the fusion with the isopropylidene ring distorts the neighboring cyclohexane ring, which possibly leads to several rapidly equilibrating twist-conformations. To the best of our knowledge, twist-conformations in the solid state for cyclohexan derivatives with one fused 1,3dioxolane unit have been reported twice ${ }^{44,45}$ in the Cambridge Crystallographic Data Bank for small molecules. Cyclohexane twist-conformations in the crystalline state are more frequently found when two 1,3-dioxolane moieties are present or if the cyclohexane ring is part of a tricyclic structure. A twist-conformation in the solid state was reported for the cyanoethylidene derivative of a six-membered carbohydrate tetrahydropyran ring. ${ }^{20}$ Increased conformational flexibility has been reported for the cyclohexane ring in hydrindanes. ${ }^{46,47}$

\section{Conclusions}

Coupling of the aminomethyl- $C$-fucopyranoside 7 with the chiral building block $(1 R, 3 R, 4 R, 5 R)$ 1,3-dihydroxy-4,5-O-isopropylidene-1-carboxy cyclohexane 1,3-lactone 9 did not yield the expected product presumably due to chemical instability of 7 . However, coupling products between the lactone 9 and benzyl-2-amino-4,6-O-benzylidene-2-deoxy- $\alpha / \beta$-D-glucopyranose $\mathbf{1 2 a} / \mathbf{b}$ and D-glucamine $\mathbf{1 4}$ were obtained in moderate to good yields. NMR analysis revealed significant cyclohexane ring flexibility with predominance of a twist-chair conformation. This was supported by molecular modeling. Apparently, the presence of the 1,3-dioxolane moiety and multiple possibilities for hydrogen bonds distorts the cyclohexane chair conformation and promotes the presence of multiple solution conformations. The class of $C$-(1,6-dideoxy- $\beta-\mathrm{D}, \mathrm{L}-$ hexapyranosyl)-methyl- $N$ - $(1 R, 3 R, 4 S, 5 R)$-1,3-dihydroxy-4,5-O-isopropylidene-cyclohexane carboxamides represent new carbohydrate analogs and may exhibit interesting biological properties as small cluster oligosaccharide mimetics (SCOM) with disaccharide-like structures.

\section{Experimental Section}

General Procedures. All reagents were used without purification unless specified. 1-Amino-1deoxy-D-glucitol (D-glucamine) was obtained from Huels America (New Jersey) and was recrystallized from water. Solvents were of HPLC grade. Dichloromethane, isopropyl ether, ethylacetate, and dioxane were purified by simple distillation prior to use. Nitromethane was stirred with Drierite for $24 \mathrm{~h}$. Solvents were removed on a Rotovap apparatus (Buechi, 
Switzerland). Column chromatography was performed with silica gel (J.T. Baker, 40-60 mesh) on a glass column with permanent reservoir (Kimble\&Kontes, 50 × 700 and $38 \times 500 \mathrm{~mm}$ ). Thin layer chromatography (TLC, $250 \mu \mathrm{m} \mathrm{\textrm {SiO } _ { 2 }}$, Analtech) was run with indicated solvent systems. The developed plates were sprayed with $10 \%$ aq. $\mathrm{H}_{2} \mathrm{SO}_{4}$, and were charred on a hot plate for visualization.

Room temperature NMR spectra were recorded in $\mathrm{CDCl}_{3}$ unless stated differently on a Varian MERCURY $300 \mathrm{MHz}$ spectrometer with spinning and were referenced to TMS as internal standard. Total Correlation Spectroscopy (TOCSY, Homonuclear Hartmann-Hahn) experiments were carried out non-spinning with a mixing time (duration of the MLEV-16 spin lock) of $50 \mathrm{~ms}$. Data were collected in the 2D-hypercomplex mode (States-Haberkorn method). All ESI mass spectra were recorded on a VARIAN $1200 \mathrm{LC}$ triple-quad mass spectrometer in positive mode. Solutions of $\mathrm{c} \sim 10^{-5} \mathrm{M}$ were used in $\mathrm{MeOH} / \mathrm{H}_{2} \mathrm{O}(1: 1)$ at $400 \mu \mathrm{L}$ total volume. The analyte solution was sprayed by continuous infusion from the tip of a capillary with pneumatic assist $\left(\mathrm{N}_{2}\right.$ sheath gas) at a flow rate of $10 \mu \mathrm{L} / \mathrm{min}$. Desolvation of the spray was accomplished at elevated temperature (MAPI chamber $=50{ }^{\circ} \mathrm{C}$, งcapillary $=120-150{ }^{\circ} \mathrm{C}$ ). The instrument was operated at $\sim 5^{*} 10^{-6}$ torr with a mass window of $m / z 0-1500$. The detector was set to 1.2-1.5 kV. High-resolution ESI mass spectra were recorded on a double focusing sector instrument (LCmate, JEOL) with polyethylene glycol as internal standard.

Molecular modeling was done on a Power Mac G5 equipped with the Spartan software package (Spartan '02 for Windows, Wavefunction, Inc., Irvine, CA). Initial structures were minimized in the MMFF94 force field (Merck Pharmaceuticals) and were subsequently subjected to searches over the conformational space with collection of the lowest structures within $20 \mathrm{kcal} / \mathrm{mol}$ of the global minimum. The lowest energy chair structures and the structures most consistent with NMR data were further optimized by the semi-empirical AM1 method.

\section{Compound characterization}

$\mathbf{1 , 2 , 3 , 4 - T e t r a - O} \boldsymbol{O}$-acetyl- $\boldsymbol{\alpha} / \mathbf{\beta}$-L-fucopyranose $(\mathbf{2 a} / \mathbf{b})$. A mixture of pyridine $(50 \mathrm{ml}, 500 \mathrm{mmol})$ and acetic anhydride $\left(\mathrm{Ac}_{2} \mathrm{O}, 50 \mathrm{ml}, 500 \mathrm{mmol}\right)$ was cooled with stirring in an ice bath. A catalytic amount of 4-( $N, N$-dimethylamino)-pyridine (DMAP, $1 \mathrm{~g}, 8.2 \mathrm{mmol})$ was dissolved in this mixture. After 15 minutes, L-fucose $(1,15 \mathrm{~g}, 100 \mathrm{mmol})$ was added in portions of $3 \mathrm{~g}$ each over the course of $1 \mathrm{~h}$ with stirring. The solution took on a light yellow color and was allowed to reach room temperature (rt) over the next $16 \mathrm{~h}$. Crushed ice $(10 \mathrm{~g})$ was added to the mixture with continued stirring for $1 \mathrm{hr}$. A mixture of concentrated $\mathrm{HCl}(50 \mathrm{ml})$ and crushed ice $(50 \mathrm{~g})$ was added to the mixture, and a white precipitate was obtained, which was filtered off and washed with ice-cold water. The crystals were dried over sulfuric acid in a vacuum desiccator to give the $\alpha$-anomer (2a) $26.03 \mathrm{~g} \mathrm{(78} \mathrm{mmol,} 78 \%$ ) with physical properties identical to published values; ${ }^{48}$ mp 90-91 ${ }^{\circ} \mathrm{C}$; TLC $\left(i-\mathrm{Pr}_{2} \mathrm{O}\right) \mathrm{R}_{\mathrm{f}}: 0.3,{ }^{1} \mathrm{H}-\mathrm{NMR}\left(\mathrm{CDCl}_{3}, \delta\right.$ in ppm, $J$ in $\left.\mathrm{Hz}\right): \delta 1.16\left(3 \mathrm{H}, \mathrm{d},{ }^{3} J_{6,5} 6.3\right.$, $\left.\mathrm{CH}_{3}\right), \delta 2.00\left(3 \mathrm{H}, \mathrm{s}, \mathrm{CH}_{3}{ }^{\mathrm{Ac}}\right), \delta 2.01\left(3 \mathrm{H}, \mathrm{s}, \mathrm{CH}_{3}{ }^{\mathrm{Ac}}\right), \delta 2.14\left(3 \mathrm{H}, \mathrm{s}, \mathrm{CH}_{3}{ }^{\mathrm{Ac}}\right), \delta 2.17\left(3 \mathrm{H}, \mathrm{s}, \mathrm{CH}_{3}{ }^{\mathrm{Ac}}\right)$, $\delta 4.26\left(1 \mathrm{H}, \mathrm{q},{ }^{3} J_{5,6} 6.3,{ }^{3} J_{5,4}<1, \mathrm{H}-5\right), \delta 5.32\left(3 \mathrm{H}, \mathrm{m}\right.$, mixing, H-2, H-3, H-4), $\delta 6.32\left(1 \mathrm{H}, \mathrm{d},{ }^{3} J_{1,2}\right.$ 2.1, H-1). 
The filtrate was extracted with $\mathrm{CH}_{2} \mathrm{Cl}_{2}(3 \times 100 \mathrm{ml})$. The $\mathrm{CH}_{2} \mathrm{Cl}_{2}$ phase was extracted with water $(50 \mathrm{ml})$, followed by $3.5 \mathrm{M} \mathrm{HCl}(2 \times 50 \mathrm{ml})$, then with water $(1 \times 50 \mathrm{ml})$, and with sat. aq. $\mathrm{NaHCO}_{3}(1 \times 50 \mathrm{ml})$, and was dried $\left(\mathrm{Na}_{2} \mathrm{SO}_{4}\right)$. The dried organic layer was evaporated in vacuo to yield a syrup (6.5 g, $20 \mathrm{mmol}, 20 \%)$. TLC ( $i$ - $\left.\operatorname{Pr}_{2} \mathrm{O}\right) \mathrm{R}_{\mathrm{f}}$ : 0.3 ( $\alpha$-anomer), 0.2 ( $\beta$-anomer).

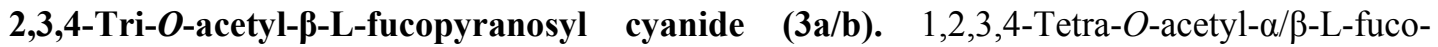
pyranose $(\mathbf{2 a} / \mathbf{b}, \alpha / \beta$-ratio $\sim 15: 1,19.87 \mathrm{~g}, 59.6 \mathrm{mmol})$ was dissolved in anhydrous $\mathrm{MeNO}_{2}$ (100 ml) containing $\mathrm{HgBr}_{2}(2.86 \mathrm{~g}, 7.94 \mathrm{mmol})$ and $\mathrm{Me}_{3} \mathrm{SiCN}(23.84 \mathrm{ml}, 18.27 \mathrm{mmol}) .{ }^{19}$ The mixture slowly took on a deep red-brown color, was stirred for $12 \mathrm{~h}$ at $\mathrm{rt}$, and was evaporated in vacuo. The residue was treated with $\mathrm{CH}_{2} \mathrm{Cl}_{2}(150 \mathrm{ml})$, and insoluble material $\left(\mathrm{HgBr}_{2}\right)$ was filtered off (Celite). The filter cake was washed with $\mathrm{CH}_{2} \mathrm{Cl}_{2}(2 \times 50 \mathrm{~mL})$. The filtrate was treated with silica gel $(10 \mathrm{~g})$ followed by filtration. The procedure was repeated once more, and the clear solution was evaporated in vacuo. Traces of $\mathrm{CH}_{2} \mathrm{Cl}_{2}$ were removed by repeated evaporation of EtOH ( $3 \times 20 \mathrm{~mL})$ in vacuo. Treatment of the residual oil with a minimal amount of hot EtOH yielded off-white crystals of the $\beta$-anomer $\mathbf{3 b}$ upon cooling $(5.5 \mathrm{~g}, 31 \%$ ) with physical properties identical to the literature. ${ }^{19} \mathrm{Mp} .124-125{ }^{\circ} \mathrm{C}$, TLC (i- $\left.\mathrm{Pr}_{2} \mathrm{O}\right) \mathrm{R}_{\mathrm{f}} 0.53$; ${ }^{1} \mathrm{H}-\mathrm{NMR}$ $\left(\mathrm{CDCl}_{3}, \delta\right.$ in ppm, $J$ in Hz): $\delta 1.22\left(3 \mathrm{H}, \mathrm{d},{ }^{3} J_{6,5} 6.6, \mathrm{CH}_{3}\right), \delta 2.00\left(3 \mathrm{H}, \mathrm{s}, \mathrm{CH}_{3}{ }^{\mathrm{Ac}}\right), \delta 2.11(3 \mathrm{H}, \mathrm{s}$, $\left.\mathrm{CH}_{3}{ }^{\mathrm{Ac}}\right), \delta 2.20\left(3 \mathrm{H}, \mathrm{s}, \mathrm{CH}_{3}{ }^{\mathrm{Ac}}\right), \delta 3.81\left(1 \mathrm{H}, \mathrm{dq},{ }^{3} J_{5,6} 6.3,{ }^{3} J_{5,4} 0.9, \mathrm{H}-5\right), \delta 4.25\left(1 \mathrm{H}, \mathrm{d},{ }^{3} J_{1,2} 10.2\right.$, $\mathrm{H}-1), \delta 4.98\left(1 \mathrm{H}, \mathrm{dd},{ }^{3} J_{3,2} 10.2,{ }^{3} J_{3,4} 3.3, \mathrm{H}-3\right), \delta 5.26\left(1 \mathrm{H}, \mathrm{dd},{ }^{3} J_{4,3} 3.3,{ }^{3} J_{4,5} 0.6, \mathrm{H}-4\right), \delta 5.50$ $\left(1 \mathrm{H}, \mathrm{t},{ }^{3} J_{2,1} 10.2,{ }^{3} J_{2,3} 10.2, \mathrm{H}-2\right) ;{ }^{13} \mathrm{C}-\mathrm{NMR}\left(\mathrm{CDCl}_{3}, \delta\right.$ in $\left.\mathrm{ppm}\right): \delta 16.10,20.48,20.50,20.55$, $66.06,66.74,69.61,71.19,74.27,114.54,168.58,169.62,170.07$. The residue from the recrystallization was an $\alpha / \beta$-mixture that could not be crystallized.

\section{Separation of $\boldsymbol{N}$ - $t$-butyloxycarbonyl- $C$ - $\beta$-aminomethyl-2,3,4-tri- $O$-acetyl-L-fucopyranoside monosaccharide (4) and $N$ - $t$-butyloxycarbonyl- $N$ - $[C$ - $\beta$-methyl-2,3,4-tri- $O$-acetyl-L-fuco pyranosyl]- $\boldsymbol{C}$ - $\boldsymbol{\beta}$-aminomethyl-2,3,4-tri- $\boldsymbol{O}$-acetyl-L-fucopyranoside disaccharide $(5)^{19}$}

The hydrogenation of $\mathbf{3 a} / \mathbf{b}$ was carried out by a published procedure. ${ }^{19}$ A mixture of $8.1 \mathrm{~g} 4$ and 5 was applied to the column. The column was developed with plain $i-\operatorname{Pr}_{2} \mathrm{O}(2 \times 1 \mathrm{~L})$, followed by a mixture of $i-\mathrm{Pr}_{2} \mathrm{O} / \mathrm{EtOAc}(20: 1,2 \times 1 \mathrm{~L})$. Final elution was done with plain EtOAc $(500 \mathrm{~mL})$. Fractions of $\sim 150 \mathrm{~mL}$ were collected and checked by TLC $\left(i-\mathrm{Pr}_{2} \mathrm{O} / \mathrm{EtOAc} 9: 1\right)$ for presence of compounds. Fractions corresponding to the monosaccharide 4 were combined and evaporated to give 6.03g (18.9 mmol, 75\%) of colorless foam. TLC (i- $\left.\mathrm{Pr}_{2} \mathrm{O}\right) \mathrm{R}_{\mathrm{f}}: 0.5 ;{ }^{1} \mathrm{H}-\mathrm{NMR}\left(\mathrm{CDCl}_{3}, \delta\right.$ in ppm, $J$ in $\mathrm{Hz}): \delta 1.17\left(3 \mathrm{H}, \mathrm{d},{ }^{3} J_{\mathrm{CH} 3,5} 6.6, \mathrm{CH}_{3}\right), \delta 1.42(9 \mathrm{H}, \mathrm{s}, t-\mathrm{Bu}), \delta 1.73\left(1 \mathrm{H}, \mathrm{m}, \mathrm{CH}^{\mathrm{a}} \mathrm{N}\right), \delta 1.97$ $\left(3 \mathrm{H}, \mathrm{s}, \mathrm{CH}_{3}{ }^{\mathrm{Ac}}\right), \delta 2.06\left(3 \mathrm{H}, \mathrm{s}, \mathrm{CH}_{3}{ }^{\mathrm{Ac}}\right), \delta 2.18\left(3 \mathrm{H}, \mathrm{s}, \mathrm{CH}_{3}{ }^{\mathrm{Ac}}\right), \delta 3.11\left(1 \mathrm{H}, \mathrm{m}, \mathrm{CH}^{\mathrm{b}} \mathrm{N}\right), \delta 3.47(1 \mathrm{H}$, subm., H-1), $\delta 3.77$ (1H, dq q $\left.,{ }^{3} J_{5,4}<1,{ }^{3} J_{5, \mathrm{CH} 3} 6.3, \mathrm{H}-5\right), \delta 4.96(1 \mathrm{H}, \mathrm{t} \sim \mathrm{s}$, subm., NH), $\delta 5.01$ (1H, dd, subm., $\left.{ }^{3} J_{3,2} 10.2,{ }^{3} J_{3,4} 3.6, \mathrm{H}-3\right), \delta 5.08$ (1H, t, $\left.{ }^{3} J_{2,1} 9.6,{ }^{3} J_{2,3} 9.6, \mathrm{H}-2\right), \delta 5.25(1 \mathrm{H}$, dd, $\left.{ }^{3} J_{4,3} 3.3,{ }^{3} J_{4,5} 1.2, \mathrm{H}-4\right) ;{ }^{13} \mathrm{C}-\mathrm{NMR}\left(\mathrm{CDCl}_{3}, \delta\right.$ in ppm): $\delta 16.32,20.61,20.68,20.75,28.35,36.24$, 41.42, 50.54, 66.96, 70.73, 72.33, 72.71, 79.45, 155.45, 169.64, 169.95, 170.35. HRES ESI-MS: theor.: $\mathrm{C}_{18} \mathrm{H}_{29} \mathrm{NO}_{9} \mathrm{MW}_{\text {monoisotopic }} 403.18 \mathrm{u}$; obs.: [M+H-Boc] $304.13 \mathrm{~m} / \mathrm{z}$.

Fractions of the disaccharide 5 were treated analogously to give $1.82 \mathrm{~g}(3.8 \mathrm{mmol}, 22 \%)$ of colorless foam. TLC (i- $\left.\mathrm{Pr}_{2} \mathrm{O}\right) \mathrm{R}_{\mathrm{f}}$ : $0.25\left(i-\mathrm{Pr}_{2} \mathrm{O}\right.$ :EtOAc 9:1); ${ }^{1} \mathrm{H}-\mathrm{NMR}\left(\mathrm{CDCl}_{3}, \delta\right.$ in ppm, $J$ in $\left.\mathrm{Hz}\right)$ : 
$\delta 1.10\left(6 \mathrm{H}, \mathrm{d},{ }^{3} J_{6,5} 6.3, \mathrm{CH}_{3}\right), \delta 1.89\left(3 \mathrm{H}, \mathrm{s}, \mathrm{CH}_{3}{ }^{\mathrm{Ac}}\right), \delta 1.90\left(3 \mathrm{H}, \mathrm{s}, \mathrm{CH}_{3}{ }^{\mathrm{Ac}}\right), \delta 1.96\left(3 \mathrm{H}, \mathrm{s}, \mathrm{CH}_{3}{ }^{\mathrm{Ac}}\right)$, $\delta 2.00\left(3 \mathrm{H}, \mathrm{s}, \mathrm{CH}_{3}{ }^{\mathrm{Ac}}\right), \delta 2.13\left(6 \mathrm{H}, \mathrm{s}, \mathrm{CH}_{3}{ }^{\mathrm{Ac}}\right), \delta 3.06\left(1 \mathrm{H}, \mathrm{dd},{ }^{3} J_{\mathrm{CH} l a, 2} 9.0,{ }^{2} J_{\mathrm{CH} l a, \mathrm{CH} l b} 14.4, \mathrm{CH}^{\mathrm{a}} \mathrm{N}\right)$,

$\delta 3.12\left(1 \mathrm{H}, \mathrm{dd},{ }^{3} J_{\mathrm{CH}{ }^{\prime}, 2} 9.0,{ }^{2} J_{\mathrm{CH}^{\prime} \mathrm{a}, \mathrm{CH} b} 15.3, \mathrm{CH}^{\prime a} \mathrm{~N}\right), \delta 3.42-3.70\left(6 \mathrm{H}, \mathrm{m}, \mathrm{H}-1, \mathrm{H}-1{ }^{\prime}, \mathrm{CH}^{\mathrm{b}} \mathrm{N}\right.$, $\mathrm{CH}^{\prime b} \mathrm{~N}, \mathrm{H}-5, \mathrm{H}-5^{\prime}$ ), $\delta$ 4.88-4.98 (4H, m, H-2, H-2', H-3, H-3'), $\delta 5.17$ (2H, m, H-4, H-4'); ${ }^{13} \mathrm{C}-$ NMR $\left(\mathrm{CDCl}_{3}, \delta\right.$ in ppm): $\delta 16.78,21.01,21.16,21.29,28.70,28.82,50.39,50.77,67.95,68.12$, 71.08, 71.18, 72.77, 72.81, 72.96, 73.02, 78.28, 78.77, 80.23, 155.03, 169.99, 170.22, 170.37, 170.79; HRESMS ESI-MS: theor: $\mathrm{C}_{31} \mathrm{H}_{47} \mathrm{NO}_{16} \mathrm{MW}_{\text {monoisotopic }}$ 689.29; obs.: $[\mathrm{M}+\mathrm{H}-\mathrm{Boc}]^{+} \mathrm{m} / \mathrm{z}$ 590.33 .

$(1 R, 3 R, 4 R, 5 R)$-1,3-Dihydroxy-4,5-O-isopropylidene-1-carboxy cyclohexane 1,3-lactone (9). ${ }^{36}$ A solution of quinic acid $(2 \mathrm{~g}, 10 \mathrm{mmol})$ and $p$-toluenesulfonic acid $(p-\mathrm{TsOH}, 0.1 \mathrm{~g}$, $0.5 \mathrm{mmol})$ in acetone $(100 \mathrm{~mL})$ was heated at reflux in a flask equipped with a Soxhlet extractor filled with Drierite for $6 \mathrm{~h}$. A glass wool plug was installed in the Soxhlet thimble above the Drierite to prevent spilling during drainage. After $6 \mathrm{~h}$, the solution was stirred with finely powdered anhydrous $\mathrm{NaHCO}_{3}(3 \mathrm{~g})$ at rt overnight and was filtered. The filtrate was evaporated, and the crude product was recrystallized from $i-\mathrm{Pr}_{2} \mathrm{O}$ to give $2.06 \mathrm{~g}(5.6 \mathrm{mmol}, 91 \%)$ of colorless needle-shaped crystals. Mp. $140-141{ }^{\circ} \mathrm{C} ;{ }^{1} \mathrm{H}$-NMR see Table $1 ;{ }^{13} \mathrm{C}-\mathrm{NMR}\left(\mathrm{CDCl}_{3}, \delta\right.$ in ppm): $\delta$ $24.65,27.33,34.63,36.56,36.58,38.60,71.80,72.39,76.13,110.01,178.84$.

Carboxamides from amines and compound 9. General procedure: A solution of the amine ( $2 \mathrm{mmol}$ ) and compound 9 ( $2 \mathrm{mmol})$ in 20 drops of dimethylacetamide (DMA) was heated with stirring at $70{ }^{\circ} \mathrm{C}$ for $48 \mathrm{~h}$, and was kept at $\mathrm{rt}$ for an additional $48 \mathrm{~h}$. The syrup was diluted with diethyl ether $\left(\mathrm{Et}_{2} \mathrm{O}\right)$, the crystals were filtered off and were washed with little ice-cold $\mathrm{Et}_{2} \mathrm{O}$.

Carboxamide coupling product 11 from benzylamine 10 and compound 9. Compound 9 $(0.25 \mathrm{~g}, 1.16 \mathrm{mmol})$ was dissolved in DMA $(\sim 20 \mu \mathrm{L})$ and benzylamine $(0.13 \mathrm{ml}, 1.9 \mathrm{mmol})$. The solution was heated for 5 days at $70^{\circ} \mathrm{C}$. The residue was crystallized with i-Pr-OH, and the crude product was recrystallized with fresh i-Pr-OH. Off-white crystals $(0.31 \mathrm{~g}, 0.91 \mathrm{mmol}, 80 \%),{ }^{1} \mathrm{H}-$ NMR see Table $1 ;{ }^{13} \mathrm{C}-\mathrm{NMR}\left(\mathrm{CDCl}_{3}, \delta\right.$ in ppm): $\delta .40,24.67,27.34,34.74,36.56,37.41,43.67$, $66.08,72.32,73.15,76.14,76.85,77.27,77.47,77.69,127.73,127.85,128.98$; HRES ESI-MS: theor.: $\mathrm{C}_{17} \mathrm{H}_{23} \mathrm{NO}_{5} \mathrm{MW}_{\text {monoisotopic }} 321.16$ u; obs.: $[\mathrm{M}+\mathrm{H}]^{+} \mathrm{m} / \mathrm{z} 322.10[\mathrm{M}+\mathrm{Na}]^{+} \mathrm{m} / \mathrm{z} 344.14$.

Carboxamide coupling products $13 \mathrm{a}$ and $13 \mathrm{~b}$ from benzyl-2-amino-4,6-O-benzylidene-2deoxy- $\alpha / \beta-D-g l u c o p y r a n o s e ~ 12 a$ or $12 b$ and compound 9. Benzyl-2-amino-4,6-O-benzylidene 2-deoxy- $\alpha$-D-glucopyranoside $12 \mathrm{a}(0.71 \mathrm{~g}, 2 \mathrm{mmol})$ and compound $9(0.43 \mathrm{~g}, 2 \mathrm{mmol})$ were treated according to the general procedure to yield colorless crystals of $13 \mathrm{a}(0.27 \mathrm{~g}, 0.76 \mathrm{mmol}$, $38 \%$ ): Mp $177{ }^{\circ} \mathrm{C} ;{ }^{1} \mathrm{H}-\mathrm{NMR}$ see Table $1 ;{ }^{13} \mathrm{C}-\mathrm{NMR}\left(\mathrm{CDCl}_{3}, \delta\right.$ in ppm): $\delta 24.69,27.40,34.57$, $37.36,53.98,63.04,66.36,69.02,69.98,70.53,72.47,73.38,76.53,82.24,96.98,102.14$, $108.96,126.51,128.40,128.46,128.56,128.84,129.49,136.81,137.27,177.83 ;{ }^{13} \mathrm{C}-\mathrm{NMR}$ (DMSO-d ${ }_{6}, \delta$ in ppm, J in Hz): $\delta 25.48,28.01,31.01,35.81,54.11,63.00,66.97,67.72,68.51$, $72.83,73.57,80.26,81.39,96.43,100.78,107.29,126.22,127.49,127.52,127.87,128.18$, 128.73, 137.20, 137.46, 175.94; HRES ESI-MS: theor.: $\mathrm{C}_{30} \mathrm{H}_{37} \mathrm{NO}_{10} \mathrm{MW}_{\text {monoisotopic }}=571.24 \mathrm{u}$; obs.: $[\mathrm{M}+\mathrm{H}]^{+} \mathrm{m} / \mathrm{z} 572.28$. 
The $\beta$-D-glucopyranoside was treated analogously to yield colorless crystals of $\mathbf{1 3 b}(0.663 \mathrm{~g}$, $1.86 \mathrm{mmol}, 93 \%) \mathrm{Mp} 194{ }^{\circ} \mathrm{C} ;{ }^{1} \mathrm{H}-\mathrm{NMR}$ see Table $1 ;{ }^{13} \mathrm{C}-\mathrm{NMR}\left(\mathrm{CDCl}_{3}, \delta\right.$ in ppm): $\delta 24.66$, $27.35,34.49,37.26,58.35,66.24,66.57,68.83,71.16,71.25,72.39,73.43,76.39,81.69,99.76$, $102.13,108.96,126.56,128.26,128.35,128.53,128.80,129.47,136.91,137.26,178.00 ;{ }^{13} \mathrm{C}-$ NMR (DMSO-d 6 , $\delta$ in ppm, J in Hz): $\delta ~ 25.32,27.88,36.28,55.78,65.81,66.99,67.72,69.85$, 70.03, 72.76, 73.36, 80.22, 81.15, 100.45, 101.13, 107.13, 126.09, 126.91, 127.10, 127.76, 127.86, 128.58, 137.50, 175.87; HRES ESI-MS: theor.: $\mathrm{C}_{30} \mathrm{H}_{37} \mathrm{NO}_{10} \mathrm{MW}_{\text {monoisotopic }}=571.24 \mathrm{u}$; obs.: $[\mathrm{M}+\mathrm{H}]^{+} \mathrm{m} / \mathrm{z} 572.25$.

Carboxamide coupling product 15 from 1-amino-1-deoxy-D-glucitol (D-glucamine) 14 and compound 9. Industrial-grade D-glucamine 14 (10 g) was dissolved in hot water $(10 \mathrm{~mL})$. While hot, a layer of EtOH was carefully placed on top of the solution, and the mixture was stored at $0{ }^{\circ} \mathrm{C}$ overnight. The crystals were filtered and were washed sequentially with water, EtOH, diethyl ether, and were dried in a desiccator over conc. $\mathrm{H}_{2} \mathrm{SO}_{4}$. Recrystallized Dglucamine $(0.36 \mathrm{~g}, 1.98 \mathrm{mmol})$ and compound $9(0.42 \mathrm{~g}, 2 \mathrm{mmol})$ were treated according to the general procedure. After heating, a mixture of water/EtOH (1:1) was added and evaporated. Subsequently, a mixture of EtOH/toluene (1:1) was added and evaporated. The syrup was diluted with $\mathrm{Et}_{2} \mathrm{O}$, and $\mathrm{i}-\mathrm{Pr}-\mathrm{OH}$ was added to the mixture, the solution was stored in the refrigerator overnight. A gelatinous precipitate was obtained, which yielded an amorphous colorless solid upon filtration and drying $(0.49 \mathrm{~g}, 1.20 \mathrm{mmol}, 62 \%) .{ }^{1} \mathrm{H}-\mathrm{NMR}$ (DMSO-d $\mathrm{d}_{6}, \delta$ in ppm, J in Hz): $\delta$ $1.30\left(3 \mathrm{H}, \mathrm{s}, \mathrm{CH}_{3}{ }^{\mathrm{i}-\mathrm{Pr}}\right), \delta 1.44\left(3 \mathrm{H}, \mathrm{s}, \mathrm{CH}_{3}{ }^{\mathrm{i}-\mathrm{Pr}}\right), \delta 1.95\left(1 \mathrm{H}, \mathrm{dd},{ }^{3} \mathrm{~J}_{3 \mathrm{~A}, 2 \mathrm{~A}} 4.5,{ }^{3} \mathrm{~J}_{3 \mathrm{~A}, 4 \mathrm{~A}} 8.1, \mathrm{H}-3^{\mathrm{A}}\right), \delta 2.03$ $\left(1 \mathrm{H}\right.$, subm., H-6a $\left.{ }^{\mathrm{B}}\right), \delta 2.28\left(1 \mathrm{H}, \mathrm{dd},{ }^{2} \mathrm{~J}_{6 \mathrm{bB}, 6 \mathrm{aB}} 15.3,{ }^{3} \mathrm{~J}_{6 \mathrm{bB}, 5 \mathrm{~B}} 4.2, \mathrm{H}-6 \mathrm{~b}^{\mathrm{B}}\right), \delta 5.33$ (1H, ddd, $\left.{ }^{2} \mathrm{~J}_{\mathrm{CH} 1 \mathrm{bA}, \mathrm{CH} 1 \mathrm{aA}} 13.5,{ }^{3} \mathrm{~J}_{\mathrm{CH} 1 \mathrm{bA}, \mathrm{NHA}} 5.1,{ }^{3} \mathrm{~J}_{\mathrm{CH} 1 \mathrm{bA}, \mathrm{H} 2 \mathrm{~A}} 6.6, \mathrm{CH}-1 \mathrm{~b}^{\mathrm{A}}\right), \delta 3.51$ (1H, ddd, ${ }^{2} \mathrm{~J}_{\mathrm{CH} 1 \mathrm{aA}, \mathrm{CH} 1 \mathrm{bA}} 13.5$, $\left.{ }^{3} \mathrm{~J}_{\mathrm{CH} 1 \mathrm{aA}, \mathrm{NHA}} 4.8,{ }^{3} \mathrm{~J}_{\mathrm{CH} 1 \mathrm{aA}, \mathrm{H} 2 \mathrm{~A}} 6.6, \mathrm{CH}-1 \mathrm{a}^{\mathrm{A}}\right), \delta 3.60-3.92(7 \mathrm{H}, \mathrm{m}), \delta 3.98\left(1 \mathrm{H}, \mathrm{dd},{ }^{3} \mathrm{~J}_{4 \mathrm{~B}, 3 \mathrm{~B}} 4.8,{ }^{3} \mathrm{~J}_{4 \mathrm{~B}, 5 \mathrm{~B}}\right.$ $\left.6.3, \mathrm{H}-4^{\mathrm{B}}\right), \delta 4.34(1 \mathrm{H}, \mathrm{d}, \mathrm{OH}), \delta 4.51\left(1 \mathrm{H}, \mathrm{dt},{ }^{3} \mathrm{~J}_{5 \mathrm{~B}, 4 \mathrm{~B}} 6.6,{ }^{3} \mathrm{~J}_{5 \mathrm{~B}, 6 \mathrm{aB}} 3.9,{ }^{3} \mathrm{~J}_{5 \mathrm{~B}, 6 \mathrm{bB}} 3.9, \mathrm{H}-5^{\mathrm{B}}\right), \delta 4.85$ $(1 \mathrm{H}, \mathrm{d}, \mathrm{OH}), \delta 7.78(1 \mathrm{H}, \mathrm{t} \sim \mathrm{s}, \mathrm{NH}) ;{ }^{13} \mathrm{C}-\mathrm{NMR}\left(\mathrm{CDCl}_{3}, \delta\right.$ in ppm): $\delta 24.82,27.47,35.34,38.63$, 42.33, 64.01, 64.13, 67.05, 67.16, 70.25, 71.96, 72.52, 73.18, 78.78, 108.19; HRES ESI-MS: theor. $\mathrm{C}_{16} \mathrm{H}_{29} \mathrm{NO}_{10} \mathrm{MW}_{\text {monoisotopic }} 395.18 \mathrm{u}$; obs.: $[\mathrm{M}+\mathrm{H}]^{+} \mathrm{m} / \mathrm{z} 396.11$.

\section{Acknowledgements}

The authors would like to acknowledge a Senior Scientist Mentor Award through the Dreyfus Foundation to P.G. and financial support by the Department of Chemistry at the University of the Pacific. We thank Dr. Vyacheslav V. Samoshin for the PCMODEL calculations and valuable discussions. 


\section{References}

1. Mareel, M.; Leroy, A. Physiol. Rev. 2003, 83, 337.

2. Burleigh, B. A.; Woolsey, A. M. Cell. Microbiol. 2002, 4, 701.

3. Muramatsu, T. Glycoconj. J. 2000, 17, 577.

4. Wu, A. M. J. Biomed. Sci. 2003, 10, 676.

5. Medzihradszky, K. F.; Spencer, D. I. R.; Sharma, S. K.; Bhatia, J.; Pedley, R. B.; Read, D. A.; Begent, R. H. J.; Chester, K. A. Glycobiology 2004, 14, 27.

6. Misra, S.; Ghatak, S.; Zoltan-Jones, A.; Toole, B. P. J. Biol. Chem. 2003, $278,25285$.

7. Nangia-Makker, P.; Conklin, J.; Hogan, V.; Raz, A. Trends Mol. Med. 2002, 8, 187.

8. Nishimura, Y. Curr. Topics Med. Chem. 2003, 3, 575.

9. Keding, S. J.; Danishefsky, S. J. Proc. Natl. Acad. Sci. 2004, 101, 11937.

10. Ragupathi, G.; Coltart, D. M.; Williams, L. J.; Koide, F.; Kagan, E.; Allen, J.; Harris, C.; Glunz, P. W.; Livingston, P. O.; Danishefsky, S. J. Proc. Natl. Acad. Sci. 2002, 99, 13699.

11. Nyame, A. K.; Kawar, Z. S.; Cummings, R. D. Arch. Biochem. Biophys. 2004, 426, 182.

12. Seeberger, P. H. Chem. Commun. 2003, 1115.

13. Seeberger, P. H.; Danishefsky, S. J. Acc. Chem. Res. 1998, 31, 685.

14. Lu, J.; Jayaprakash, K. N.; Schlueter, U.; Fraser-Reid, B. J. Am. Chem. Soc. 2004, 126, 7540 .

15. Lu, J.; Jayaprakash, K. N.; Fraser-Reid, B. Tetrahedron Lett. 2004, 45, 879.

16. Gagneux, P.; Varki, A. Glycobiology 1999, 9, 747.

17. Liu, L.; McKee, M.; Postema, M. H. D. Curr. Org. Chem. 2001, 5, 1133.

18. Compain, P.; Martin, O. R. Bioorg. Med. Chem. 2001, 9, 3077.

19. Phiasivongsa, P.; Gallagher, J.; Chen, C.-N.; Jones, P. R.; Samoshin, V. V.; Gross, P. H. Org. Lett. 2002, 4, 4587.

20. Gross, P. H.; Franz, A. H.; Samoshin, V. V. In Recent Res. Develop. Org. Chem. Transworld Research Network: Trivandrum, India, 2004; Vol. 8, p 255.

21. Gremyachinskiy, D. E.; Samoshin, V. V.; Gross, P. H. Tetrahedron Lett. 2003, 44, 6587.

22. Fischer, H. O. L. Ber. 1921, 54B, 775.

23. Fischer, H. O. L.; Dangschat, G. Helv. Chim. Acta 1935, 18, 1206.

24. Fischer, H. O. L.; Dangschat, G. Helv. Chim. Acta 1935, 18, 1204.

25. Fischer, H. O. L.; Dangschat, G. Helv. Chim. Acta 1934, 17, 1200.

26. Herrmann, K. M.; Weaver, L. M. Annu. Rev. Plant Physiol. Plant Mol. Biol. 1999, $50,473$.

27. Jiang, S.; Singh, G. Tetrahedron 1998, 54, 4697.

28. Lee, J.-C.; Tai, C.-A.; Hung, S.-C. Tetrahedron Lett. 2002, 43, 851.

29. El Khadem, H. S.; Swartz, D. L.; Nelson, J. K.; Berry, L. A. Carbohydr. Res. 1977, 58, 230.

30. Franz, A. H.; Wei, Y. Q.; Samoshin, V. V.; Gross, P. H. J. Org. Chem. 2002, 67, 7662.

31. Wei, Y. Masters thesis, The Chemistry of 2,3-Unsaturated Glycosyl Cyanides University of the Pacific, 1991.

32. McNaught, A. D. Pure Appl. Chem. 1996, 68, 1919. 
33. McNaught, A. D. Carbohydr. Res. 1997, 297, 1.

34. McNaught, A. D. J. Carbohydr. Chem. 1997, 16, 1191.

35. McNaught, A. D. Glycoscience 2001, 3, 2753.

36. Trost, B. M.; Romero, A. G. J. Org. Chem. 1986, 51, 2332.

37. Perrin, C. L.; Dwyer, T. J. Chem. Rev. 1990, 90, 935.

38. Zhang, K.; Franz, A.; Hill, G. C.; McCallum, C. M.; Minch, M. J. Magn. Reson. Chem. 1999, 37, 788.

39. Miyai, K.; Gross, P. H. J. Org. Chem. 1969, 34, 1638.

40. Miyai, K.; Jeanloz, R. W. Carbohydr. Res. 1972, 21, 57.

41. SPARTAN; 02 ed. 2002.

42. PCMODEL; 3.2 ed.; Serena Software: Bloomington, IN, USA, 1998.

43. Gajewski, J. J.; Gilbert, K. E.; McKelvey, J. Adv. Mol. Mod. 1990, 2, 65.

44. Jaynes, B. H.; Elliott, N. C.; Jefson, M. R.; Koss, D. A.; Schicho, D. L. J. Org. Chem. 1994, $59,1224$.

45. Donohoe, T. J.; Blades, K.; Moore, P. R.; Waring, M. J.; Winter, J. J. G.; Helliwell, M.; Newcombe, N. J.; Stemp, G. J. Org. Chem. 2002, 67, 7946.

46. Moniz, W. B.; Dixon, J. A. J. Am. Chem. Soc. 1961, 83, 1671.

47. Schneider, H. J.; Nguyen-Ba, N. Org. Magn. Reson. 1982, 18, 38.

48. Collins, P. M. Carbohydrates 1987, p 227 and references cited therein. 